Article

\title{
Assessing Exergy-Based Economic and Sustainability Analyses of a Military Gas Turbine Engine Fueled with Various Fuels
}

\author{
Burak Yuksel ${ }^{1, *}$, Huseyin Gunerhan ${ }^{1}$ and Arif Hepbasli ${ }^{2}$ \\ 1 Department of Mechanical Engineering, Ege University, Bornova, Izmir 35100, Turkey; \\ huseyin.gunerhan@ege.edu.tr \\ 2 Department of Energy Engineering, Yasar University, Bornova, Izmir 35100, Turkey; \\ arif.hepbasli@yasar.edu.tr \\ * Correspondence: 91150001044@ogrenci.ege.edu.tr; Tel.: +90-538-306-8812
}

Received: 7 July 2020; Accepted: 24 July 2020; Published: 25 July 2020

\begin{abstract}
This research put forth exergy-based economic and sustainability analyses of a (J85-GE-5H) military turbojet engine (TJE). Firstly, sustainability, conventional exergoeconomic and advanced exergoeconomic cost analyses were executed utilizing kerosene fuel according to real engine working circumstances. The engine was likewise investigated parametrically, considering $\mathrm{H}_{2}$ fuel utilization. The sustainable economic analysis assessment of the TJE was finally actualized by comparing the acquired outcomes for both fuels. The entire engine's unit exergy cost of product $\left(c_{\mathrm{Pr}}\right)$ with kerosene was determined $76.45 \$ / G J$ for the military (MIL) process mode (PM), whereas it was computed $94.97 \$ / G$ J for the afterburner (AB) PM. Given the use of $\mathrm{H}_{2}$, the $c_{\mathrm{Pr}}$ increased to 179 and $288 \$ / G J$ for the aforementioned two modes, seriatim. While the sustainability cost index (SCI) values were obtained 52.86 and $78.84 \$ / G$ J for the MIL and AB PM, seriatim, they became 128 and 244 \$/GJ when considering $\mathrm{H}_{2}$. Consequently, the higher exergy demolitions occurring in the afterburner exhaust duct (ABED) and combustion chamber (CC) sections led to higher exergy destruction costs in the TJE. However, the engine worked less cost efficient with $\mathrm{H}_{2}$ fuel rather than JP-8 fuel because of the higher cost value of fuel.
\end{abstract}

Keywords: turbojet engine; sustainability analysis; performance assessment; advanced exergoeconomic analysis; $\mathrm{H}_{2}$ fuel; cost effectiveness

\section{Introduction}

Energy is an underlying phenomenon in thermodynamics and the production phase of energy is based on the notable applications of engineering examination. The systems which generate power are designed simple in order to convert energy into another. Regardless of energy, type and mode of production, it takes place in every aspect of life as a parameter that constitutes the most important agenda of our near future. The increase in energy demand is directly proportional to technological development, population and economic growth. In this context, the increase in global warming and air pollution has become the focus of energy analysis because of post-combustion products released into the atmosphere [1-4]. Aviation, standing out as the sector that creates the most energy consumption and the most pollution, is the main field of international research [5-11]. In order to provide the basis for sustainable environment-friendly policies, the road map provided in the 2018 report predicts that fossil energy resources will provide a significant share in energy production by the 2040s [12]. Energy engineers must deal with the reduction of oil reserves in the world by taking into account the increase in oil prices and environmental concerns by that time. This then draws the attention of researchers as an important issue, waiting to be resolved. Therefore, the importance of using alternative 
energy sources after exhaustion of fossil fuels stands out at this point. In this regard, hydrogen fuel, as a least-contaminant and eco-friendly resource, has been considered in research to alter these challenges. Fuel cell systems have become prominent in these studies with feasible results [13-24]. However, as time goes by, it has been determined that hydrogen has its disadvantages as well as its advantages [25-30]. The difficulties in obtaining and storing the hydrogen have become the serious challenges to be solved in aviation sector [31-33].

As is well-known, thermodynamic principles, on which the aircraft propulsion systems are based, are regarded as potent methods to assess systems in terms of efficiency and sustainability aspects. However, the performance analysis is the simultaneous evaluation of the energy efficiency obtained from energy sources and the cost effectiveness. Therefore, researchers aim to minimize the cost formation and environmental effects of aircraft engines in order to get maximum efficiency from the system by implementing design improvements and configuration changes [34-40]. This sustainable target can be achieved by using the highest quality fuel with the lowest fuel rate, reducing the exergy consumptions and minimizing the cost of investment regardless of the type of fuel utilized. Therefore, from an integrated viewpoint, aircraft engines have been considered and evaluated in scientific research not only with thermodynamic analysis but also with economic analysis. In accordance with the thermodynamic rules, exergy analysis is carried out to put forth the irreversible processes leading to exergy destructions in the system [41-47]. However, the interpretation of the irreversible processes will be completed by the implementation of the economic analysis. Economic analysis ensures cost values for investment, operating and maintenance and exergy flows. Exergoeconomic analysis, which integrates exergy and economic analyses, has been carried out in the gas turbine system to highlight the significant sections to be improved [37,48-53]. Researchers can perform a more comprehensive analysis by examining the interactions of sections with each other in terms of the value of exergy destructions as well as the value of investment costs in a gas turbine engine. Although the cost value of inefficiencies as a result of thermodynamic irreversible processes can be examined by conventional exergoeconomic analysis, further evaluation can only be attained via advanced exergoeconomic analysis by examining the provenance of the irreversible processes and recovery capacity in terms of cost to get accurate results [54-62].

In contrast to prior research, the J85-GE-5H turbojet engine's (TJE) comparative cost analyses, taking into account advanced exergoeconomic analyses by using hydrogen fuel, have not been perceived in the course of the literature review. The main significance and the individuality of this research can be summarized by numerically analyzing the mentioned analyses as follows:

- Reckon the exergy destruction costs of the entire engine and sections;

- Investigate the exergy, exergoeconomic and sustainability performance parameters for the military (MIL) and afterburner (AB) process modes (PM) for both kerosene and hydrogen fuel utilizations;

- Assign advanced exergoeconomic cost rates of the entire engine and sections by breaking them down to unavoidable/avoidable and exogenous/endogenous portions;

- Check the advanced exergoeconomic cost rates for both kerosene and hydrogen fuel utilizations;

- Reveal the sections that can be ameliorated by calculating economic benefit of amelioration potential (EBAP) for JP-8 and $\mathrm{H}_{2}$ fuels.

\section{Methodology}

\subsection{Specification of TJE}

(J85-GE-5H) TJE has high impulse and lightness characteristics provided by the integrated eight-level axial compressor and two-level axial turbine. The compressor (AC) and gas turbine (GT) consist of rotor (moving) and stator (fixed) blades. Rows of rotor and stator fins form a stage. There are six cellular-circular combustion chambers (CC) between the AC and the GT. The second part, where post-combustion occurs, is called the afterburner exhaust duct (ABED). The burning process 
takes place in the orbicular CC and ABED sections. The basic configuration sections that form the TJE are as listed below:

- Compressor (AC)

- Combustion chamber (CC)

- Gas turbine mechanical shaft (GTMS)

- $\quad$ Gas turbine (GT)

- $\quad$ Forward exhaust duct (FED)

- Afterburner exhaust duct (ABED)

The technical parameters are demonstrated as follows:

The power output was reckoned with the values of 5106 and $8575 \mathrm{~kW}$ for the MIL and AB PM, seriatim [63]. The take-off thrust is $25.80 \mathrm{kN}$, the outside diameter of the TJE is $0.52 \mathrm{~m}$, the engine length is $2.75 \mathrm{~m}$, the engine weight is $265 \mathrm{~kg}$, the flight speed range is $301-1004 \mathrm{~m} / \mathrm{s}$, the maximum operating altitude is $45,000 \mathrm{ft}$ and the starting altitude range is $0-25,000 \mathrm{ft}$ [64].

In this study, a cost analysis of J85-GE-5H TJE, used in T-38 training aircraft, was assessed with regards to its thermodynamic and thermoeconomic aspects. In this context, exergy-based sustainability, exergoeconomic and advanced exergoeconomic analyses of the engine were executed by considering the calculated costs in line with the data obtained from the engine test unit. The experimental throughput has been displayed in the control unit in order to trace values such as pressure $(\mathrm{P})$, mass rates $(\dot{m})$ and temperature $(\mathrm{T})$, which have been obtained by indicators attached on the TJE. As the engine worked in the engine test cell, the inlet duct was not taken into account in the analysis [63]. The physicochemical properties of JP-8 and $\mathrm{H}_{2}$ are indicated as follows:

The kerosene fuel consists of approximately $9 \% C_{8}-C_{9}$ aliphatic hydrocarbons, $65 \% C_{10}-C_{14}$ aliphatic hydrocarbons, $7 \% \mathrm{C}_{15}-\mathrm{C}_{17}$ aliphatic hydrocarbons and $18 \%$ aromatics with molecular weight: $\approx 180$, synonyms: JP-8, freezing point maximum: $-47^{\circ} \mathrm{C}$, boiling point: $175-300{ }^{\circ} \mathrm{C}$, vapor pressure: $0.52 \mathrm{~mm} \mathrm{Hg}\left(10^{\circ} \mathrm{C}\right), 1.8 \mathrm{~mm} \mathrm{Hg}\left(28^{\circ} \mathrm{C}\right)$, specific gravity: minimum: $0.775 \mathrm{~kg} / \mathrm{L}\left(15^{\circ} \mathrm{C}\right)$, maximum: $0.840 \mathrm{~kg} / \mathrm{L}\left(15^{\circ} \mathrm{C}\right)$, the lower heating value (LHV) $119,450 \mathrm{~kJ} / \mathrm{kg}$ and viscosity: $810^{-6} \mathrm{~kg} /(\mathrm{m} \cdot \mathrm{s})$ $\left(-20^{\circ} \mathrm{C}\right)$ [65]. The liquefied hydrogen consists of two hydrogen atoms with molecular weight: 2.0159 , synonyms: $\mathrm{H}_{2}$, melting point: $-259.35^{\circ} \mathrm{C}$, boiling point: $-252.88^{\circ} \mathrm{C}$, the $\mathrm{LHV} 43,124 \mathrm{~kJ} / \mathrm{kg}$, density (gas): $0.08988 \mathrm{~g} / \mathrm{L}\left(0{ }^{\circ} \mathrm{C}, 1 \mathrm{~atm}\right)$ and density (liquid): $70.8 \mathrm{~g} / \mathrm{L}\left(\right.$ at $\left.-253{ }^{\circ} \mathrm{C}\right)$ [66]. The air entering the engine is pressurized in the compressor section and passes to the combustion chamber section. Here, the mixture formed with pulverized sprayed JP-8 jet fuel is burned with spark plugs. The burnt gases expand in the GT and create mechanical work. While some of the mechanical work provides the movement of the $\mathrm{AC}$ and other engine accessories by rotating the mechanical shaft, the remaining part provides the necessary thrust for the flight. An extra impulse that may be needed depending on the flight characteristic is achieved by burning the sprayed $A B$ fuel with the combustion gases in the ABED section. A basic cross section of TJE and the flow directions of air and gases are shown in Figure 1.

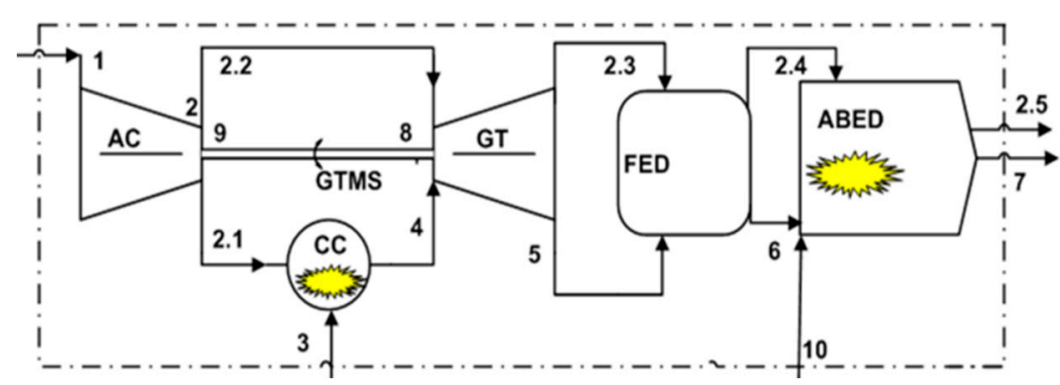

Figure 1. A simply view and flow diagram of the turbojet engine (TJE) [63].

\subsection{The Flow Process of the Analyses}

The main flow process of the analyses is charted as shown in Figure 2. 


\section{Define and solve exergy and cost balance equations}

\section{Determine and solve exergy, sustainability and exergoeconomic performance parameters}

\section{Determine and solve advanced exergoeconomic equations}

\section{Evaluate analyses results}

Figure 2. A flow process of the analyses.

The process starts with the definition of the process and ends up with the analyses of the outcomes of the study.

\subsection{Assumptions Made}

The listed assumptions are given as follows:

- Calculations for air and burnout gases were considered with the ideal gas assumption.

- The TJE operated under constant conditions.

- The fully burned gases were gained upon the completion of the operation.

- Not only in kinetic exergy but also in potential exergy, no changes occur.

- The inlet velocity $\left(\mathrm{V}_{\text {in }}\right)$ was considered zero because of the constant test conditions.

- The heat transfer ratios in AC and GT sections were regarded adiabatic [6,15].

- Kerosene and hydrogen are taken into account as fuels in this research.

\subsection{Exergy Analysis}

Exergy, an effective appliance, uses not only the second law of thermodynamics, but also the principles of mass and energy conservation. Exergy makes it possible to use the energy resources more efficiently by considering the best performance of the gas turbine systems because it can state the site and amount of wastes. In other words, the consumption of exergy leads to an entropy production as an output of the irreversible processes in a system. The general balance equation regarding the exergy is expressed as follows:

$$
\sum_{n}\left(1-\frac{T_{o}}{T_{n}}\right) \dot{Q}_{n}-\dot{W}+\sum_{\text {in }} \dot{E} x_{i n}-\sum_{o u t} \dot{E} x_{o u t}-\dot{E} x_{D}=0
$$

The $\dot{Q}_{n}, \dot{W}, \dot{E} x$ and $\dot{E} x_{D}$ represent the ratio of heat transfer at $T_{n}$ temperature, the ratio of work, the flow ratio of exergy and the ratio of exergy destruction, seriatim.

The equation regarding the exergy can be expressed as follows $[15,41,42]$ :

$$
\dot{E} x_{F}=\dot{E} x_{\mathrm{Pr}}+\dot{E} x_{D}
$$

where $\dot{E} x_{F}$ and $\dot{E} x_{\operatorname{Pr}}$ represent the ratio of fuel exergy and the ratio of product exergy, seriatim.

The $\dot{E} x_{L}$ and $\dot{E} x_{C}$ represent the exergy losses and exergy consumption, seriatim. The sum of $\dot{E} x_{L}$ and $\dot{E} x_{D}$ is $\dot{E} x_{C}[6,63]$ :

$$
\dot{E} x_{C}=\dot{E} x_{D}+\dot{E} x_{L}
$$




\subsection{Conventional Exergoeconomic Analysis}

The method of exergy analysis is utilized to assess thermodynamically the inefficiencies arising from irreversible processes. The assessment of the inefficiencies in the system by assigning cost values expresses the economic dimension of engineering analysis. The analysis method, which deals with the engineering analysis of the system integrated with exergy-based thermodynamic and economic analysis, is called exergoeconomic analysis. Exergoeconomic analysis takes into account all the expenditures made during the life cycle starting from the design phase of the system. It provides an extensive assessment opportunity. The types of costs can be determined by the exergoeconomic analysis method with (i) investment costs, (ii) maintenance and operating costs, (iii) exergy destruction costs and (iv) exergy loss costs $[4,48,50]$. There is more than one method in the literature related to the exergoeconomic analysis. The Specific Exergy Cost (SPECO) method was applied in this research. This method involves determining the exergy flows inserting and outgoing the process and solving equilibrium equations and related auxiliary equations created for unit exergy cost value analysis [35]. With this scope, the hourly levelized cost methodology has been chosen and the regarding equations have been demonstrated in Table 1 [48,49,51,52].

Table 1. The hourly levelized cost parameters of the TJE.

\begin{tabular}{cccc}
\hline Description & Unit & Equation & Equation No \\
\hline The cost rate of exergy flow, $\dot{C}_{n}$ & $(\$ / \mathrm{h})$ & $c_{n} \dot{E} x_{n}$ & $(4)$ \\
The hourly rate of total investment cost, $\dot{Z}_{n}^{T I C}$ & $(\$ / \mathrm{h})$ & $\dot{Z}_{n}^{I C}+\dot{Z}_{n}^{O M}$ & $(5)$ \\
The hourly rate of the TJE's maintenance cost, $\dot{Z}_{T J E}^{O M}$ & $(\$ / \mathrm{h})$ & $\frac{O M \dot{C}_{T J E}}{\tau}$ & $(6)$ \\
The hourly rate of maintenance cost, $\dot{Z}_{n}^{O M}$ & $(\$ / \mathrm{h})$ & $\dot{Z}_{T J E}^{O M} \frac{T I C_{n}}{T I C_{T J E}}$ & $(7)$ \\
The hourly rate of the TJE's investment cost, $\dot{Z}_{T J E}^{I C}$ & $(\$ / \mathrm{h})$ & $\frac{A C C_{T J E}}{\tau}$ & $(8)$ \\
The hourly rate of investment cost, $\dot{Z}_{n}^{I C}$ & $(\$ / \mathrm{h})$ & $\dot{Z}_{T J E}^{I C} \frac{T I C_{n}}{T I C_{T J E}}$ & $(9)$ \\
The total hourly rate of the TJE's investment cost, $\dot{Z}_{T J E}^{T I C}$ & $(\$ / \mathrm{h})$ & $\dot{Z}_{T J E}^{I C}+\dot{Z}_{T J E}^{O M}$ & $(10)$ \\
\hline
\end{tabular}
Table 2.

The equations regarding the TJE and its sections' hourly cost rate method algorithms are given in

Table 2. The cost methodology algorithms of the TJE.

\begin{tabular}{cccc}
\hline Description & Unit & Equation & Equation No \\
\hline The TJE's present worth, $P W_{T J E}$ & $(\$)$ & $T I C_{T J E}-S V_{T J E} P V F(i, n)$ & $(11)$ \\
The TJE's salvage value, $S V_{T J E}$ & $(\$)$ & $T I C_{T J E} S V R$ & $(12)$ \\
The TJE's present value factor, $P V F$ & $(-)$ & $\frac{1}{(1+i)^{n}}$ & $(13)$ \\
The TJE's yearly capital cost rate, $A \dot{C}_{T J E}$ & $(\$ / \mathrm{yr})$ & $P W_{T J E} C R F(i, n)$ & $(14)$ \\
Capital recovery factor, $C R F$ & $(-)$ & $\frac{i(i+1)^{n}}{(i+1)^{n}-1}$ & $(15)$ \\
The cost rate of yearly fuel, $F \dot{C}$ & $(\$ / \mathrm{yr})$ & $F P \dot{m}_{F} \tau 3600$ & $(16)$ \\
The TJE's hourly fuel cost rate, $\dot{C}_{F}$ & $(\$ / \mathrm{h})$ & $\frac{F \dot{C}}{\tau}$ & $(17)$ \\
\hline
\end{tabular}

\subsection{Economic Data}

The $T I C_{T J E}$ and $O M \dot{C}_{T J E}$ values of the TJE are 1,200,000 $\$$ and $72,000 \$ / y r$, seriatim [64]. The yearly working time of the system, the interest rate, the salvage value rate and the engine lifetime are assumed to be $300 \mathrm{~h} / \mathrm{yr}, 10 \%, 15 \%$ and 15 years, seriatim. While the selling price of JP- 8 is considered $0.572 \$ / \mathrm{kg}$ [64], it is considered to be $5.5 \$ / \mathrm{kg}$ for $\mathrm{H}_{2}$ fuel [52]. The $\dot{C}_{F}$ of JP-8 are reckoned 10.26 and 
$10.10 \$ / \mathrm{h}$ for MIL and AB PM, seriatim, whereas they are calculated 10.16 and $16.54 \$ / \mathrm{h}$. The cost of equipment and the hourly cost rates are shown in Table 3.

Table 3. The TJE and its sections' cost of equipment and the hourly cost rates.

\begin{tabular}{cccccc}
\hline SEC. & \multirow{2}{*}{$\boldsymbol{R}(\boldsymbol{T}(\mathbf{T})$} & $\dot{\mathbf{Z}}^{\mathbf{I C}}(\mathbf{\$})$ & $\dot{\mathbf{Z}}^{\text {OM }}(\mathbf{h})$ & $\dot{\mathbf{Z}}^{\text {TIC }}(\mathbf{h} \mathbf{h})$ \\
\hline AC & 31.67 & 380,000 & 133 & 76.00 & 209 \\
CC & 20.83 & 250,000 & 87.64 & 50.00 & 138 \\
GT & 29.17 & 350,000 & 123 & 70.00 & 193 \\
FED & 6.25 & 75,000 & 26.29 & 15.00 & 41.29 \\
ABED & 10.00 & 120,000 & 42.07 & 24.00 & 66.07 \\
GTMS & 2.08 & 25,000 & 8.76 & 5.00 & 13.76 \\
TJE & 100.00 & $1,200,000$ & 421 & 240.00 & 661 \\
\hline
\end{tabular}

Tables A1 and A2 indicate the rates of energy, exergy, mass flow, pressure and specific heat capacity for the TJE sections, seriatim, in Appendix A [63]. The equations respecting exergy and cost balance are denoted in Table 4.

Table 4. The equations respecting exergy and cost balance of the TJE.

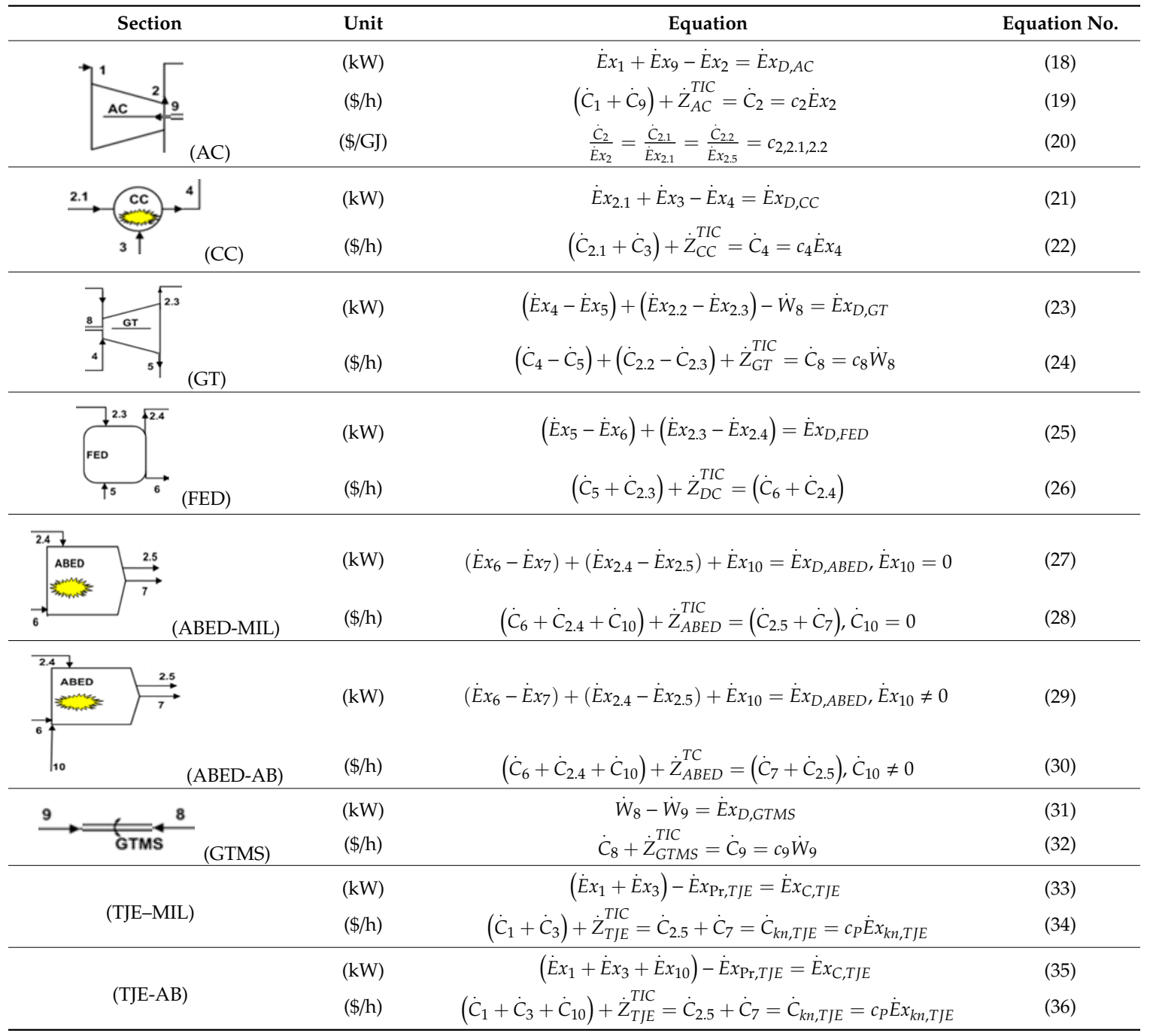




\subsection{Exergy and Exergoeconomic Performance Metrics}

The performance metrics of the TJE respecting exergy, sustainability and exergoeconomic are assigned in Table $5[6,37,44,49,63]$.

Table 5. Exergy, sustainability and exergoeconomic performance equations for the TJE.

\begin{tabular}{|c|c|c|c|}
\hline Description & Unit & Equation & Equation No \\
\hline Exergy efficiency, $\psi$ & $(\%)$ & $\dot{E} x_{\mathrm{Pr}} / \dot{E} x_{F}$ & $(37)$ \\
\hline Sustainability effect factor, $S E F$ & $(-)$ & $1 /\left(1-\psi_{n}\right)$ & (38) \\
\hline Sustainability cost index, SCI & $(\$ / G J)$ & $c_{\operatorname{Pr}}\left(1-\psi_{n}\right)$ & (39) \\
\hline Unit exergy cost rate of product, $c_{\operatorname{Pr}}$ & $(\$ / G J)$ & $\dot{C}_{\operatorname{Pr}} / \dot{E} x_{\operatorname{Pr}}$ & $(40)$ \\
\hline $\begin{array}{l}\text { Economic benefit of amelioration } \\
\text { potential rate, } E B A P_{n}\end{array}$ & $(\$ / h)$ & $\begin{array}{l}E B A P_{n}=c_{\operatorname{Pr}, n} \dot{E} x I \dot{P}= \\
c_{\operatorname{Pr}, n}\left(1-\psi_{n}\right) \dot{E} x_{C, n}\end{array}$ & $(41)$ \\
\hline Total cost rate of the TJE, $\dot{C}_{T J E}$ & $(\$ / h)$ & $\dot{C}_{F, T J E}+\dot{Z}_{T J E}^{T I C}$ & $(42)$ \\
\hline Exergy loss cost rate, $\dot{C}_{L}$ & $(\$ / h)$ & $c_{F} \dot{E} x_{L}$ & $(43)$ \\
\hline Exergy destruction cost rate, $\dot{C}_{D}$ & $(\$ / h)$ & $c_{F} \dot{E} x_{D}$ & $(44)$ \\
\hline Exergy consumption cost rate, $\dot{C}_{C}$ & $(\$ / h)$ & $c_{F}\left(\dot{E} x_{D}+\dot{E} x_{L}\right)$ & $(45)$ \\
\hline Relative cost difference, $\pi_{n}$ & $(\%)$ & $\left(c_{\operatorname{Pr}, n}-c_{F, n}\right) / c_{F, n}$ & $(46)$ \\
\hline Exergoeconomic factor, $\xi_{n}$ & $(\%)$ & $\dot{Z}_{n}^{T I C} /\left(\dot{Z}_{n}^{T I C}+\dot{C}_{D, n}\right)$ & $(47)$ \\
\hline
\end{tabular}

In accordance with Tables A1 and A2, Tables 6 and 7 demonstrate the rate of exergy, the cost rates of exergy flow and the unit exergy as per the flow state numbers, respectively.

Table 6. Values for the cost rates of exergy flow and unit exergy related to process sections for kerosene fuel use $\left({ }^{*}\right.$ : exclusively AB PM).

\begin{tabular}{ccccc}
\hline Location No & Ex $(\mathbf{k W})$ & Ex $(\mathbf{G J} / \mathbf{h})$ & $\mathbf{c}(\mathbf{\$} / \mathbf{G J})$ & $\dot{\mathbf{C}} \mathbf{( \$ / \mathbf { h } )}$ \\
\hline 0 & 0.00 & 0.00 & 0.00 & 0.00 \\
1 & 0.00 & 0.00 & 0.00 & 0.00 \\
2 & 4700 & 16.92 & 82.91 & 1403 \\
2.1 & 4230 & 15.23 & 82.91 & 1263 \\
2.2 & 470 & 1.69 & 82.91 & 140 \\
2.3 & 740 & 2.66 & 52.68 & 140 \\
2.4 & 720 & 2.59 & 54.11 & 140 \\
2.5 & 699 & 2.52 & 55.78 & 140 \\
$2.5 *$ & 1714 & 6.17 & 22.74 & 140 \\
3 & 16,554 & 59.59 & 12.49 & 745 \\
4 & 13,258 & 47.73 & 44.94 & 2145 \\
5 & 7156 & 25.76 & 44.94 & 1158 \\
6 & 6966 & 25.08 & 47.81 & 1199 \\
7 & 6746 & 24.29 & 52.09 & 1265 \\
$7 *$ & 20,164 & 72.59 & 38.46 & 2792 \\
$10 *$ & 33,941 & 122 & 12.49 & 1527 \\
8 & 5640 & 20.30 & 58.12 & 1180 \\
9 & 5583 & 20.10 & 59.39 & 1194 \\
TJE-MIL & 5106 & 18.38 & 76.45 & 1405 \\
TJE-AB & 8575 & 30.87 & 94.97 & 2932 \\
\hline
\end{tabular}


Table 7. Values for the cost rates of exergy flow and unit exergy related to process sections for hydrogen fuel use $\left({ }^{*}\right.$ : exclusively AB PM).

\begin{tabular}{ccccc}
\hline Location No & Ex (kW) & Ex $(\mathbf{G J} / \mathbf{h})$ & c (\$/GJ) & $\dot{\mathbf{C}}(\mathbf{\$} / \mathbf{h})$ \\
\hline 0 & 0.00 & 0.00 & 0.00 & 0.00 \\
1 & 0.00 & 0.00 & 0.00 & 0.00 \\
2 & 4700 & 16.92 & 174 & 2949 \\
2.1 & 4230 & 15.23 & 174 & 2654 \\
2.2 & 470 & 1.69 & 174 & 295 \\
2.3 & 710 & 2.56 & 115 & 295 \\
2.4 & 690 & 2.48 & 119 & 295 \\
2.5 & 665 & 2.39 & 123 & 295 \\
$2.5 *$ & 1677 & 6.04 & 48.84 & 295 \\
3 & 17,594 & 63.34 & 40.81 & 2585 \\
4 & 13,349 & 48.06 & 112 & 5376 \\
5 & 7059 & 25.41 & 112 & 2843 \\
6 & 6857 & 24.68 & 117 & 2884 \\
7 & 6551 & 23.59 & 125 & 2950 \\
$7 *$ & 18,853 & 67.87 & 122 & 8250 \\
$10 *$ & 36,075 & 130 & 40.81 & 5300 \\
8 & 5737 & 20.65 & 132 & 2726 \\
9 & 5583 & 20.10 & 136 & 2740 \\
TJE-MIL & 5035 & 18.13 & 179 & 3245 \\
TJE-AB & 8228 & 29.62 & 288 & 8545 \\
\hline
\end{tabular}

\section{Advanced Exergy and Exergoeconomic Analyses}

\subsection{Advanced Exergy Analysis}

Thanks to traditional exergy analysis, unproductiveness in the process is numerically obtained. Irreversible processes and losses with real development potential can be reduced by implementing advanced exergy analysis. The place and enormousness of the sources causing thermodynamic deficiencies can be described via traditional exergy analysis. It also evaluates process sections with the ultimate exergy destruction in general. The efficiency of the system sections can be ameliorated by mitigating the exergy demolition rates inside the sections. A conventional exergy analysis evaluates the process performance beneath certain operating circumstances in order to improve a step or section. However, it cannot take into account the best performance actually available from the system. It is not possible to predict the exergy amelioration capacity without considering section coactions with the conventional exergy analysis methods. These coactions, which cannot be evaluated by traditional exergy analysis, could be analyzed at length by considering the method of advanced exergy analysis $[67,68]$. Exergy destruction of each section, shown in Figure 3, is allocated to avoidable, unavoidable, exogenous and endogenous fragments.

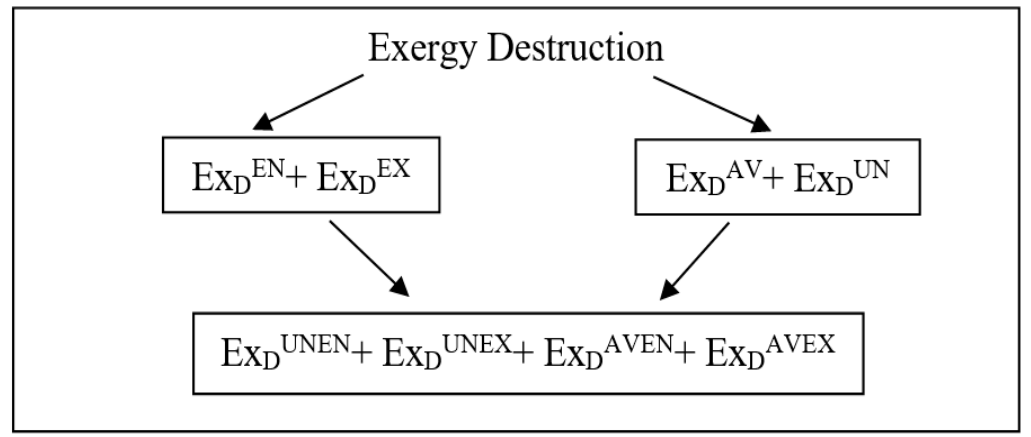

Figure 3. A schematic subdivision of exergy destruction [63]. 
The destruction respecting the endogenous division involves the section performance taking account that the leftover sections operate in optimum circumstances. The impact of the left-behind sections on the entire process forges the exogenous division of the destruction. The exergy destructions are divided into unavoidable and avoidable parts when considering the disposal capacity of irreversible processes. Though the new technologic improvements are implemented on the systems, the unavoidable division of the sections cannot be eliminated. Nevertheless, the avoidable division can be recovered per technical amelioration. Further analysis of the system can be achieved by combining the $\dot{E} x_{D}$ rates. The equations respecting advanced exergy are demonstrated in Table 8 [68-73]:

Table 8. The advanced exergy equations of the process.

\begin{tabular}{|c|c|c|c|}
\hline Description & Unit & Equation & Equation No \\
\hline Endogenous exergy destruction rate, $\dot{E} x_{D, n}^{E N}$ & $(\mathrm{GJ} / \mathrm{h})$ & $\dot{E} x_{\mathrm{Pr}, n}^{R L} \times\left(\frac{\dot{E} x_{D}}{E x_{\mathrm{Pr}}}\right)_{n}^{E N}$ & (48) \\
\hline Exogenous exergy destruction, $\dot{E} x_{D, n}^{E X}$ & $(\mathrm{GJ} / \mathrm{h})$ & $\dot{E} x_{D, n}^{E X}=\dot{E} x_{D, n}^{R L}-\dot{E} x_{D, n}^{E N}$ & (49) \\
\hline Unavoidable exergy destruction, $\dot{E} x_{D, n}^{U N}$ & $(\mathrm{GJ} / \mathrm{h})$ & $\dot{E} x_{\mathrm{Pr}, n}^{R L} \times\left(\frac{\dot{E} x_{D}}{E x_{\mathrm{Pr}_{\mathrm{r}}}}\right)_{n}^{U N}$ & (50) \\
\hline Avoidable exergy destruction, $\dot{E} x_{D, n}^{A V}$ & $(\mathrm{GJ} / \mathrm{h})$ & $\dot{E} x_{D, n}^{A V}=\dot{E} x_{D, n}^{R L}-\dot{E} x_{D, n}^{U N}$ & (51) \\
\hline Unavoidable-endogenous exergy destruction, $\dot{E} x_{D, n}^{U N E N}$ & $(\mathrm{GJ} / \mathrm{h})$ & $\dot{E} x_{D, n}^{U N E N}=\dot{E} x_{D, n}^{R L} \times\left(\frac{\dot{E} x_{D}^{u N}}{\dot{E} x_{D}^{R L}} \times \frac{\dot{E} x_{D}^{E N}}{\dot{E} x_{D}^{R L}}\right)=\frac{\dot{E} x_{D}^{u N} \times E x_{D}^{E N}}{\dot{E} x_{D}^{R L}}$ & (52) \\
\hline Unavoidable-exogenous exergy destruction, $\dot{E}_{D, n}^{U N E N}$ & $(\mathrm{GJ} / \mathrm{h})$ & $\dot{E} x_{D, n}^{U N E X}=\dot{E} x_{D, n}^{R L} \times\left(\frac{\dot{E} x_{D}^{u N}}{\dot{E} x_{D}^{R L}} \times \frac{\dot{E} x_{D}^{E X}}{\dot{E} x_{D}^{R L}}\right)=\frac{\dot{E} x_{D}^{U N} \times \dot{E}_{D}^{E X}}{\dot{E} x_{D}^{R L}}$ & (53) \\
\hline Avoidable-endogenous exergy destruction, $\dot{E} x_{D, n}^{A V E N}$ & $(\mathrm{GJ} / \mathrm{h})$ & $\dot{E} x_{D, n}^{A V E N}=\dot{E} x_{D, n}^{R L} \times\left(\frac{\dot{E} x_{D}^{A V}}{\dot{E} x_{D}^{R L}} \times \frac{\dot{E} x_{D}^{E N}}{E x_{D}^{R L}}\right)=\frac{\dot{E} x_{D}^{A V} \times \dot{E}_{D}^{E N}}{\dot{E} x_{D}^{R D}}$ & (54) \\
\hline Avoidable-exogenous exergy destruction, $\dot{E} x_{D, n}^{A V E X}$ & $(\mathrm{GJ} / \mathrm{h})$ & $\dot{E} x_{D, n}^{A V E X}=\dot{E} x_{D, n}^{R L} \times\left(\frac{\dot{E} x_{D}^{A V}}{\dot{E} x_{D}^{R L}} \times \frac{\dot{E} x_{D}^{E X}}{E x_{D}^{R L}}\right)=\frac{\dot{E} x_{D}^{A V} \times \dot{E} x_{D}^{E X}}{\dot{E} x_{D}^{R D}}$ & (55) \\
\hline
\end{tabular}

\subsection{Advanced Exergoeconomic Analysis}

The process evaluation in terms of cost is firstly executed via exergoeconomic analysis. Then, the results obtained from traditional exergoeconomic analysis are broken down into unavoidable, endogenous, avoidable and exogenous divisions for further assessment not only for the cost of exergy destruction $\dot{C}_{D, n}$ but also for the cost of investment $\dot{Z}_{n}^{T I C}$. The cost rates are combined to be assessed for further analysis as avoidable/exogenous-endogenous and unavoidable/exogenous-endogenous divisions. Traditional exergoeconomic analyses are not suitable for evaluating interactions between system steps, since it cannot take into account the optimum efficiency obtained from the system. It is not possible to estimate the EBAP without considering section interactions with traditional exergoeconomic analysis. The cost ratio of endogenous investment $\dot{Z}_{n}^{E N}$ and the cost rate of endogenous exergy destruction $\dot{C}_{D, n}^{E N}$ are computed assuming that the section under consideration is operating at real working circumstances, while the left behind sections are under theoretical conditions. Evaluating the interactions of all system components on each other and the improvement potential of each section is important for cost improvement. The unavoidable investment cost $\dot{Z}_{n}^{U N}$ refers to the inevitable cost of the section. $T I C_{n}^{U N}$ is the unavoidable cost of the purchased section that cannot be reduced due to the manufacturing restricts [54-62]. A schematic subdivision respecting $\dot{C}_{D, n}$ and $\dot{Z}_{n}^{\text {TIC }}$ are demonstrated in Figure 4. 


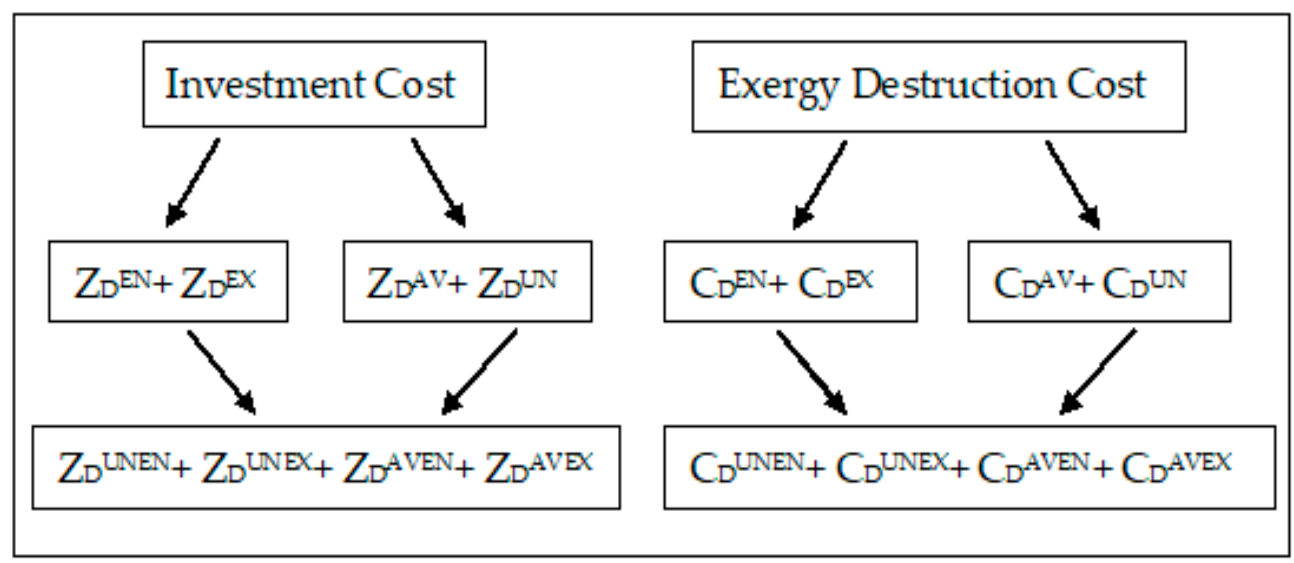

Figure 4. A schematic subdivision respecting the costs of investment and exergy destruction.

The equations respecting the $\dot{C}_{D, n}$ and the $\dot{Z}_{n}^{\text {TIC }}$ are derived and demonstrated in Table 9.

Table 9. Advanced exergoeconomic equations of investment and exergy destruction costs [55].

\begin{tabular}{ccccc}
\hline Investment Cost $\left(\dot{\mathbf{Z}}_{n}^{\text {TIC }}\right)$ & Equation No & Exergy Destruction Cost $\left(\dot{\boldsymbol{C}}_{D, n}\right)$ & Equation No & Unit \\
\hline$\dot{Z}_{n}^{E N}=\dot{E}_{P, n}^{E N} \cdot\left(\frac{\dot{Z}}{\dot{E}_{p}}\right)_{n}^{R L}$ & $(56)$ & $\dot{C}_{D, n}^{E N}=c_{F, n} \cdot \dot{E}_{D, n}^{E N}$ & $(64)$ & $(\$ / \mathrm{h})$ \\
\hline$\dot{Z}_{n}^{E X}=\dot{Z}_{n}^{R L}-\dot{Z}_{n}^{E N}$ & $(57)$ & $\dot{C}_{D, n}^{E X}=\dot{C}_{D, n}^{R L}-\dot{C}_{D, n}^{E N}$ & $(65)$ & $(\$ / \mathrm{h})$ \\
\hline$\dot{Z}_{n}^{U N}=\left(\frac{T I C U N}{T I C L}\right)_{n} \cdot \dot{Z}_{n}^{R L}$ & $(58)$ & $\dot{C}_{D, n}^{U N}=c_{F, n} \cdot \dot{E}_{D, n}^{U N}$ & $(66)$ & $(\$ / \mathrm{h})$ \\
\hline$\dot{Z}_{n}^{A V}=\dot{Z}_{n}^{R L}-\dot{Z}_{n}^{U N}$ & $(59)$ & $\dot{C}_{D, n}^{A V}=\dot{C}_{D, n}^{R L}-\dot{C}_{D, n}^{U N}$ & $(67)$ & $(\$ / \mathrm{h})$ \\
\hline$\dot{Z}_{n}^{U N, E N}=\dot{E}_{P, n}^{E N} \cdot\left(\frac{\dot{Z}_{n}^{U N}}{\dot{E}_{p}}\right)_{n}$ & $(60)$ & $\dot{C}_{D, n}^{U N, E N}=c_{F, n} \cdot \dot{E}_{D, n}^{U N, E N}$ & $(68)$ & $(\$ / \mathrm{h})$ \\
\hline$\dot{Z}_{n}^{U N, E X}=\dot{Z}_{n}^{U N}-\dot{Z}_{n}^{U N, E N}$ & $(61)$ & $\dot{C}_{D, n}^{U N, E X}=\dot{C}_{D, n}^{U N}-\dot{C}_{D, n}^{U N, E N}$ & $(69)$ & $(\$ / \mathrm{h})$ \\
\hline$\dot{Z}_{n}^{A V, E N}=\dot{Z}_{n}^{E N}-\dot{Z}_{n}^{U N, E N}$ & $(62)$ & $\dot{C}_{D, n}^{A V, E N}=\dot{C}_{D, n}^{E N}-\dot{C}_{D, n}^{U N, E N}$ & $(70)$ & $(\$ / \mathrm{h})$ \\
\hline$\dot{Z}_{n}^{A V, E X}=\dot{Z}_{n}^{E X}-\dot{Z}_{n}^{U N, E X}$ & $(63)$ & $\dot{C}_{D, n}^{A V, E X}=\dot{C}_{D, n}^{E X}-\dot{C}_{D, n}^{U N, E X}$ & $(71)$ & $(\$ / \mathrm{h})$ \\
\hline
\end{tabular}

\section{Results and Discussion}

In accordance with Tables 6 and A1, while exergetic and exergoeconomic performance metrics are shown with the use of kerosene in Table 10 for MIL PM, they are demonstrated in Table 11 for AB PM. According to the outcomes for the TJE, while the fuel exergy values were determined to be $16,554 \mathrm{~kW}(59.59 \mathrm{GJ} / \mathrm{h})$ and 50,495 $\mathrm{kW}(182 \mathrm{GJ} / \mathrm{h})$ for the MIL and the AB PM, seriatim, the product exergy values were calculated to be $5106 \mathrm{~kW}(18.38 \mathrm{GJ} / \mathrm{h})$ and $8575 \mathrm{~kW}(30.87 \mathrm{GJ} / \mathrm{h})$. Hence, the $\dot{E} x_{D}$ rates were reckoned at $11,447 \mathrm{~kW}(41.21 \mathrm{GJ} / \mathrm{h})$ and $41,920 \mathrm{~kW}(151 \mathrm{GJ} / \mathrm{h})$ for the MIL and AB PM, seriatim. The TJE's exergetic efficiency was determined $16.98 \%$ and $30.85 \%$ for the AB and MIL PM, seriatim [63]. The lowest SEF was reckoned in the CC section with the rate of 2.20 for the MIL PM, while it was computed to be 2.13 in the ABED section for the AB PM. The ultimate SCI were calculated in the CC section with the rate of $20.43 \$ / G J$ both for the AB and MIL PM. The utmost EBAP was reckoned in the CC as $154 \$ / h$ for the MIL PM, while it was computed with a rate of $644 \$ / h$ for the AB PM. Figure 5 indicates the TJE and its sections' EBAP rates with kerosene fuel use. 
Table 10. Results for exergy, exergoeconomic and sustainability performance indicators for MIL PM with kerosene fuel use.

\begin{tabular}{|c|c|c|c|c|c|c|c|c|c|c|c|c|c|}
\hline SEC. & $\dot{E} x_{F}(\mathbf{k W})$ & $\dot{E} x_{\operatorname{Pr}}(\mathbf{k W})$ & $\dot{E} x_{C}(\mathrm{~kW})$ & $\psi(\%)$ & $S E F(-)$ & $S C I(\$ / G J)$ & $E B A P(\$ / \mathrm{h})$ & $c_{F}(\$ / G J)$ & $c_{\operatorname{Pr}}(\$ / G J)$ & $\dot{C}_{C}(\$ / \mathrm{h})$ & $\dot{Z}^{T I C}(\$ / \mathrm{h})$ & $\pi(\%)$ & $\zeta(\%)$ \\
\hline $\mathrm{AC}$ & 5583 & 4700 & 883 & 84.19 & 6.32 & 13.11 & 29.84 & 59.39 & 82.91 & 189 & 209 & 39.60 & 52.57 \\
\hline $\mathrm{CC}$ & 16,554 & 9028 & 7525 & 54.54 & 2.20 & 20.43 & 154 & 12.49 & 44.94 & 338 & 138 & 260 & 28.91 \\
\hline GT & 5833 & 5640 & 193 & 96.69 & 30.23 & 1.92 & 1.06 & 46.24 & 58.12 & 32.12 & 193 & 25.69 & 85.71 \\
\hline FED & 7895 & 7686 & 209 & 97.35 & 37.70 & 1.28 & 0.91 & 45.66 & 48.40 & 34.43 & 41.29 & 5.99 & 54.53 \\
\hline ABED & 7686 & 7445 & 241 & 96.86 & 31.84 & 1.65 & 1.32 & 48.40 & 52.43 & 42.06 & 66.07 & 8.34 & 61.10 \\
\hline GTMS & 5640 & 5583 & 57.13 & 98.99 & 98.73 & 0.60 & 0.12 & 58.12 & 0.35 & 11.95 & 13.76 & 2.20 & 53.52 \\
\hline \multicolumn{2}{|c|}{ Total Destruction Rate } & - & 9109 & - & - & & - & - & - & 410 & - & - & - \\
\hline \multicolumn{2}{|c|}{ Total Losses Rate } & - & 2338 & - & - & & - & - & - & 105 & - & - & - \\
\hline TJE & 16,554 & 5106 & 11,447 & 30.85 & 1.45 & 52.86 & 356 & 12.49 & 76.45 & 515 & 661 & 512 & 56.20 \\
\hline
\end{tabular}

Table 11. Results for exergy, exergoeconomic and sustainability performance indicators for AB PM with kerosene fuel use.

\begin{tabular}{|c|c|c|c|c|c|c|c|c|c|c|c|c|c|}
\hline SEC. & $\dot{E} x_{F}(\mathbf{k W})$ & $\dot{E} x_{\operatorname{Pr}}(\mathrm{kW})$ & $\dot{E} x_{C}(\mathbf{k W})$ & $\psi(\%)$ & $S E F(-)$ & $S C I(\$ / G J)$ & $E B A P(\$ / \mathrm{h})$ & $c_{F}(\$ / G J)$ & $c_{\operatorname{Pr}}(\$ / G J)$ & $\dot{C}_{C}(\$ / \mathbf{h})$ & $\dot{Z}^{T I C}(\$ / \mathrm{h})$ & $\pi(\%)$ & $\zeta(\%)$ \\
\hline $\mathrm{AC}$ & 5583 & 4700 & 883 & 84.19 & 6.32 & 13.11 & 29.84 & 59.39 & 82.91 & 189 & 209 & 39.60 & 52.57 \\
\hline $\mathrm{CC}$ & 16,554 & 9028 & 7525 & 54.54 & 2.20 & 20.43 & 154 & 12.49 & 44.94 & 338 & 138 & 260 & 28.91 \\
\hline GT & 5833 & 5640 & 193 & 96.69 & 30.23 & 1.92 & 1.06 & 46.24 & 58.12 & 32.12 & 193 & 25.69 & 85.71 \\
\hline FED & 7895 & 7686 & 209 & 97.35 & 37.70 & 1.28 & 0.91 & 45.66 & 48.40 & 34.43 & 41.29 & 5.99 & 54.53 \\
\hline ABED & 41,606 & 21,878 & 19,728 & 52.58 & 2.11 & 17.65 & 644 & 19.12 & 37.23 & 1360 & 66.07 & 94.66 & 4.63 \\
\hline GTMS & 5640 & 5583 & 57.13 & 98.99 & 98.73 & 0.60 & 0.12 & 58.12 & 0.35 & 11.95 & 13.76 & 2.20 & 53.52 \\
\hline \multicolumn{2}{|c|}{ Total Destruction Rate } & - & 28,595 & - & - & - & & - & - & 1286 & - & - & - \\
\hline \multicolumn{2}{|c|}{ Total Losses Rate } & - & 13,324 & - & - & - & & - & - & 599 & - & - & - \\
\hline TJE & 50,495 & 8575 & 41,920 & 16.98 & 1.20 & 78.84 & 1565 & 12.49 & 94.97 & 1886 & 661 & 660 & 25.95 \\
\hline
\end{tabular}




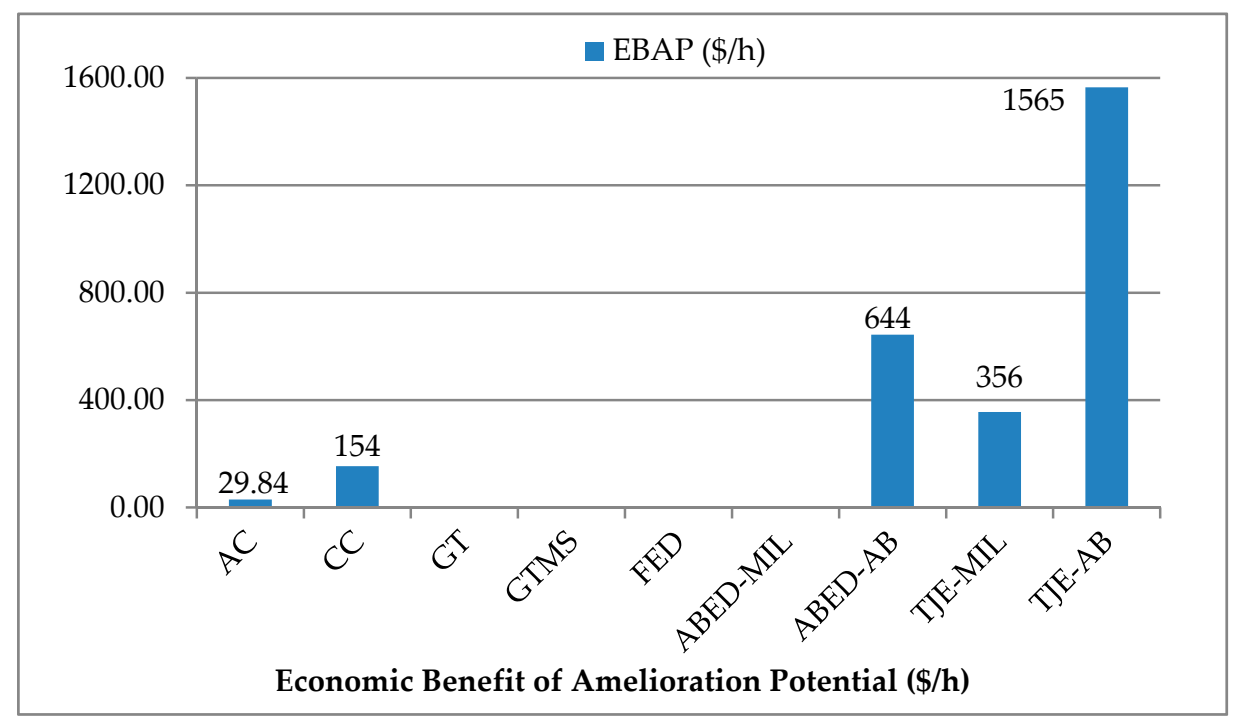

Figure 5. Economic profit of amelioration potential (EBAP) with JP-8 fuel usage.

The overall SEF of the engine was computed 1.20 and 1.45 for AB and MIL PM, seriatim, while SCI was reckoned with the rates of 78.84 and $52.86 \$ / G J$. In accordance with the ameliorated potential of the system, the EBAP was determined to be 356 and $1565 \$ / \mathrm{h}$ for MIL and AB PM, seriatim. The maximum $\dot{Z}^{T I C}$ was calculated with the rate of $209 \$ / \mathrm{h}$ in AC section, whereas it was reckoned at $13.76 \$ / \mathrm{h}$ in the GTMS section with the minimum rate for both aforementioned modes. As per Table $6, \dot{C}_{\text {TJE }}$ was reckoned at $1405 \$ / \mathrm{h}$ for the MIL PM, while it was calculated to be $2932 \$ / \mathrm{h}$ for AB PM. According to Figure 6 , the $\pi$ and the $\zeta$ of the entire process were determined $512 \%$ and $56.20 \%$ for the MIL PM, whereas they were computed $660 \%$ and $25.95 \%$ for the AB PM, seriatim. The cost ratios and the indicators of the sustainability and exergy related to the engine sections are demonstrated below.

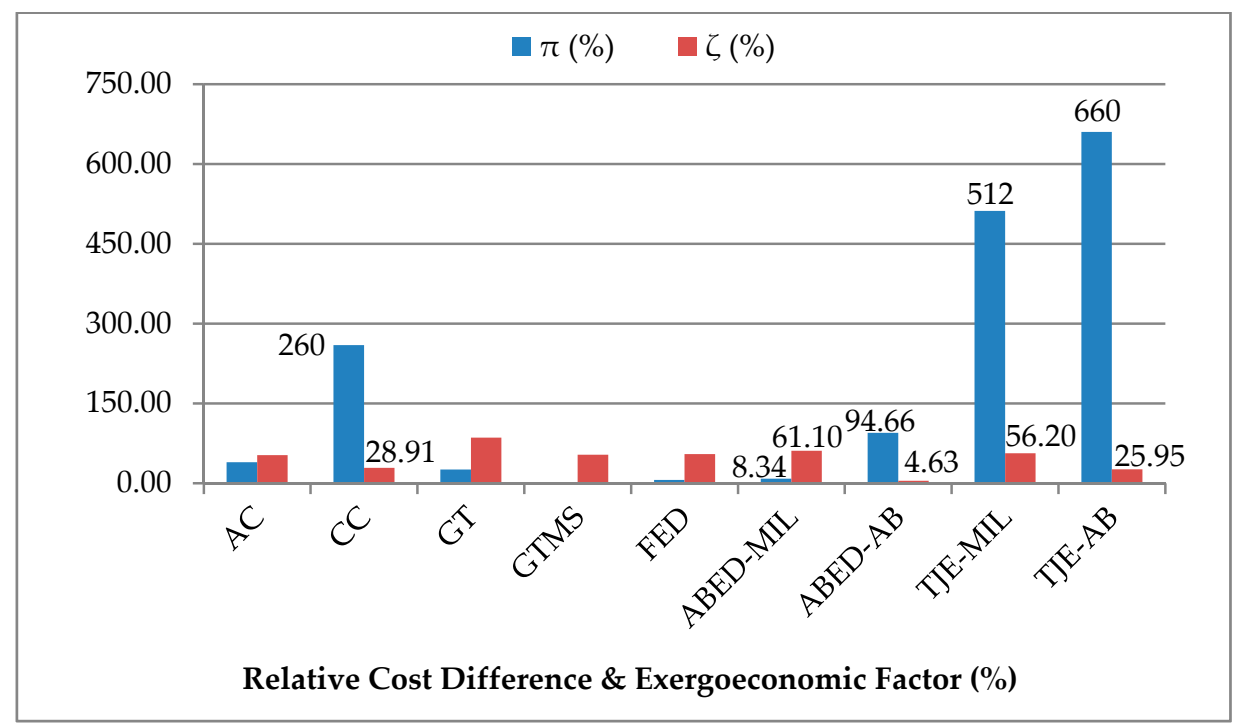

Figure 6. Relative cost difference $(\pi)$ and exergoeconomic factor $(\zeta)$ with JP-8 fuel usage. 
With respect to Table 10, the maximum unit fuel cost rate was calculated in the AC section, which had a rate of $59.39 \$ / G J$, while it was reckoned at $12.49 \$ / G J$ for the entire engine. Moreover, the AC section had the ultimate unit product cost with the rate of $82.91 \$ / G J$, while it was calculated to be $76.45 \$ / G J$ for the whole engine. The utmost $\dot{C}_{C}$ and the $\pi$ were determined at $338 \$ / h$ and $260 \%$ in the CC section, seriatim, while they were reckoned at $515 \$ / \mathrm{h}$ and $512 \%$ for the whole engine. Therewithal, CC section had the minimum $\zeta$ with $28.91 \%$.

With respect to Table 11, the ultimate unit fuel cost rate was calculated in the AC section, which had a rate of $59.39 \$ / G J$, while it was reckoned at $12.49 \$ / G J$ for the entire engine. Moreover, the AC section had the ultimate unit product cost with a rate of $82.91 \$ / G \mathrm{~J}$, while it was calculated to be $94.97 \$ / G \mathrm{~J}$ for the entire engine. The utmost $\dot{C}_{C}$ was determined at $1360 \$ / \mathrm{h}$ in the ABED section, while it was reckoned at $1886 \$ / \mathrm{h}$ for the whole engine. In addition, ABED section had the minimum $\zeta$ with $4.63 \%$.

In accordance with Tables 7 and A2, while exergetic and exergoeconomic performance metrics are shown with the use of hydrogen in Table 12 for MIL PM, they are demonstrated in Table 13 for AB PM. According to the outcomes for the TJE, while the fuel exergy values were determined to be $17,594 \mathrm{~kW}$ $(63.34 \mathrm{GJ} / \mathrm{h})$ and $53,669 \mathrm{~kW}(193 \mathrm{GJ} / \mathrm{h})$ for the MIL and AB PM, seriatim, the product exergy rates were calculated to be $5035 \mathrm{~kW}(18.13 \mathrm{GJ} / \mathrm{h})$ and $8228 \mathrm{~kW}(29.62 \mathrm{GJ} / \mathrm{h})$. Hence, the $\dot{E} x_{D}$ rates were reckoned at $12,559 \mathrm{~kW}(45.21 \mathrm{GJ} / \mathrm{h})$ and 45,441 kW (164 GJ/h) for MIL and AB PM, seriatim. The TJE's exergetic efficiency was determined at $15.33 \%$ and $28.62 \%$ for the AB and MIL PM, seriatim [63]. The lowest SEF was reckoned in the CC section with a rate of 2.08 for the MIL PM, while it was computed to be 1.89 in the ABED section for the AB PM. The ultimate SCI were calculated in the CC section with a rate of 53.89 \$/GJ for the MIL PM, while it was computed at 61.17 \$/GJ for AB PM. The utmost EBAP was reckoned in the CC with a rate of $600 \$ / \mathrm{h}$ for the MIL PM, while it was computed to be at a rate of $2372 \$ / h$ for the AB PM. Figure 7 indicates the EBAP of the TJE and its sections with the usage of $\mathrm{H}_{2}$ fuel.

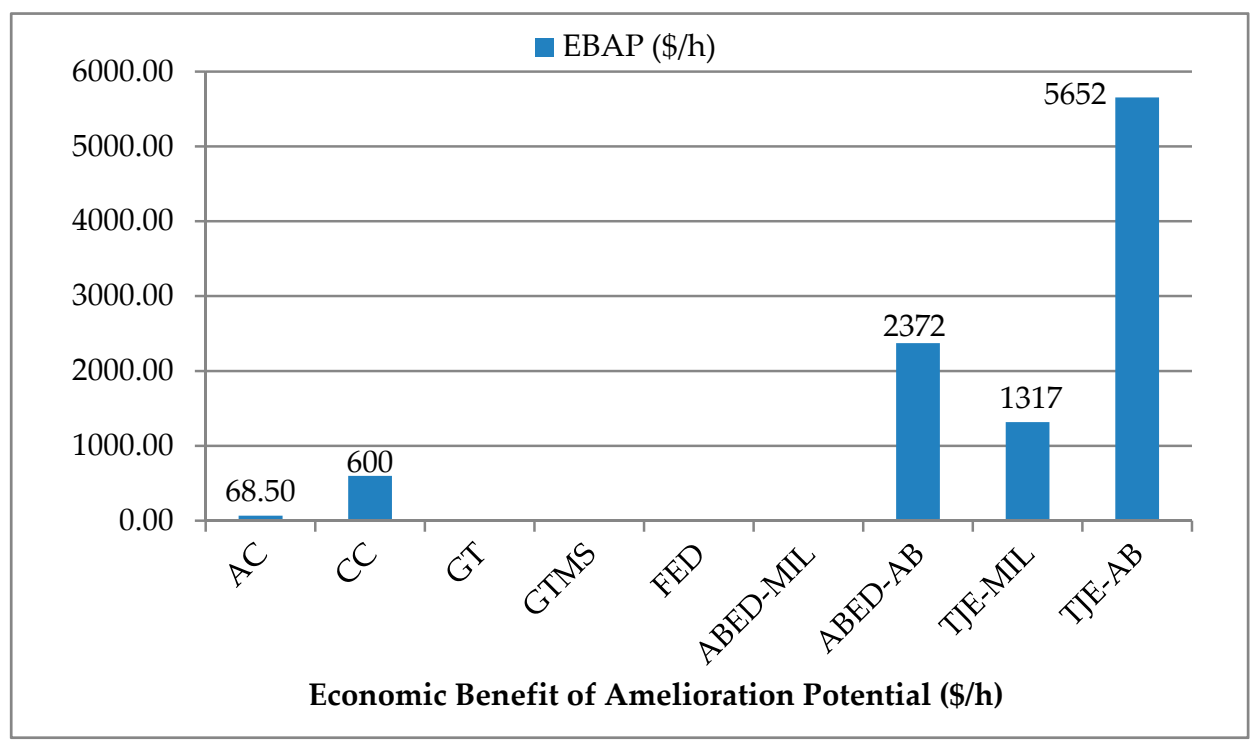

Figure 7. Economic benefit of amelioration potential (EBAP) with $\mathrm{H}_{2}$ fuel usage. 
Table 12. Results for exergy, exergoeconomic and sustainability performance indicators for MIL PM with hydrogen fuel use.

\begin{tabular}{|c|c|c|c|c|c|c|c|c|c|c|c|c|c|}
\hline SEC. & $\dot{E} x_{F}(\mathbf{k W})$ & $\dot{E} x_{\operatorname{Pr}}(\mathbf{k W})$ & $\dot{E} x_{C}(\mathrm{~kW})$ & $\psi(\%)$ & $S E F(-)$ & $S C I(\$ / G J)$ & $\operatorname{EPIP}(\$ / \mathrm{h})$ & $c_{F}(\$ / G J)$ & $c_{\operatorname{Pr}}(\$ / G J)$ & $\dot{C}_{C}(\$ / \mathrm{h})$ & $\dot{Z}^{T I C}(\$ / \mathrm{h})$ & $\pi(\%)$ & $\zeta(\%)$ \\
\hline $\mathrm{AC}$ & 5583 & 4700 & 883 & 84.19 & 6.32 & 27.56 & 68.50 & 136 & 174 & 433 & 209 & 27.85 & 32.57 \\
\hline $\mathrm{CC}$ & 17,594 & 9119 & 8475 & 51.83 & 2.08 & 53.89 & 600 & 40.81 & 112 & 1245 & 138 & 174 & 9.95 \\
\hline GT & 6050 & 5737 & 313 & 94.82 & 19.32 & 6.83 & 6.65 & 114 & 132 & 129 & 193 & 15.78 & 59.99 \\
\hline FED & 7769 & 7546 & 223 & 97.13 & 34.88 & 3.36 & 2.58 & 112 & 117 & 90 & 41.29 & 4.31 & 31.46 \\
\hline ABED & 7546 & 7216 & 330 & 95.62 & 22.84 & 5.47 & 6.09 & 117 & 125 & 139 & 66.07 & 6.75 & 32.19 \\
\hline GTMS & 5737 & 5583 & 154 & 97.31 & 37.16 & 3.67 & 1.97 & 132 & 136 & 73.37 & 13.76 & 3.28 & 15.80 \\
\hline \multicolumn{2}{|c|}{ Total Destruction Rate } & - & 10,378 & - & - & & - & - & 1525 & - & - & & - \\
\hline \multicolumn{2}{|c|}{ Total Losses Rate } & - & 2181 & - & - & & - & - & 320 & - & - & & - \\
\hline TJE & 17,594 & 5035 & 12,559 & 28.62 & 1.40 & 128 & 1317 & 40.81 & 179 & 1845 & 661 & 339 & 26.37 \\
\hline
\end{tabular}

Table 13. Results for exergy, exergoeconomic and sustainability performance indicators for AB PM with hydrogen fuel use.

\begin{tabular}{|c|c|c|c|c|c|c|c|c|c|c|c|c|c|}
\hline SEC. & $\dot{E} x_{F}(\mathbf{k W})$ & $\dot{E} x_{\operatorname{Pr}}(\mathrm{kW})$ & $\dot{E} x_{C}(\mathbf{k W})$ & $\psi(\%)$ & $S E F(-)$ & $S C I(\$ / G J)$ & $E P I P(\$ / h)$ & $c_{F}(\$ / G J)$ & $c_{\operatorname{Pr}}(\$ / G J)$ & $\dot{C}_{C}(\$ / \mathrm{h})$ & $\dot{Z}^{T I C}(\$ / \mathrm{h})$ & $\pi(\%)$ & $\zeta(\%)$ \\
\hline $\mathrm{AC}$ & 5583 & 4700 & 883 & 84.19 & 6.32 & 27.56 & 68.50 & 136 & 174 & 433 & 209 & 27.85 & 32.57 \\
\hline $\mathrm{CC}$ & 17,594 & 9119 & 8475 & 51.83 & 2.08 & 53.89 & 600 & 40.81 & 112 & 1245 & 138 & 174 & 9.95 \\
\hline GT & 6050 & 5737 & 313 & 94.82 & 19.32 & 6.83 & 6.65 & 114 & 132 & 129 & 193 & 15.78 & 59.99 \\
\hline FED & 7769 & 7546 & 223 & 97.13 & 34.88 & 3.36 & 2.58 & 112 & 117 & 90 & 41.29 & 4.31 & 31.46 \\
\hline ABED & 43,596 & 20,530 & 23,066 & 47.09 & 1.89 & 61.17 & 2372 & 53.99 & 116 & 4488 & 66.07 & 114 & 1.45 \\
\hline GTMS & 5737 & 5583 & 154 & 97.31 & 37.16 & 3.67 & 1.97 & 132 & 136 & 73.37 & 13.76 & 3.28 & 15.80 \\
\hline \multicolumn{2}{|c|}{ Total Destruction Rate } & - & 33,113 & - & - & - & - & - & - & 4865 & - & - & - \\
\hline \multicolumn{2}{|c|}{ Total Losses Rate } & - & 12,327 & - & - & - & - & - & - & 1811 & - & - & - \\
\hline TJE & 53,669 & 8228 & 45,441 & 15.33 & 1.18 & 244 & 5,652 & 40.81 & 288 & 6676 & 661 & 607 & 9.01 \\
\hline
\end{tabular}


The overall SEF of the engine was computed to be 1.18 and 1.40 for AB and MIL PM, seriatim, while SCI was reckoned with rates of 128 and $244 \$ / G J$. In accordance with the ameliorated potential of the system, the EBAP was determined to be 1317 and 5652 \$/h for MIL and AB PM, seriatim. The maximum $\dot{Z}^{\text {TIC }}$ was calculated with a rate of $209 \$ / \mathrm{h}$ in the AC section, whereas it was reckoned at $13.76 \$ / \mathrm{h}$ in GTMS section with the minimum rate for both aforementioned PMs. As per Table 7 , $\dot{C}_{T J E}$ was reckoned at $3245 \$ / \mathrm{h}$ for MIL PM, while it was calculated to be $8545 \$ / \mathrm{h}$ for AB PM. As per Figure 8 , the $\pi$ and the $\zeta$ of the entire system were determined to be $339 \%$ and $26.37 \%$ for the MIL PM, whereas they were computed to be $607 \%$ and $9.01 \%$ for the AB PM, seriatim. The cost rates and the indicators of sustainability and exergy related to engine sections are demonstrated in Figure 8.

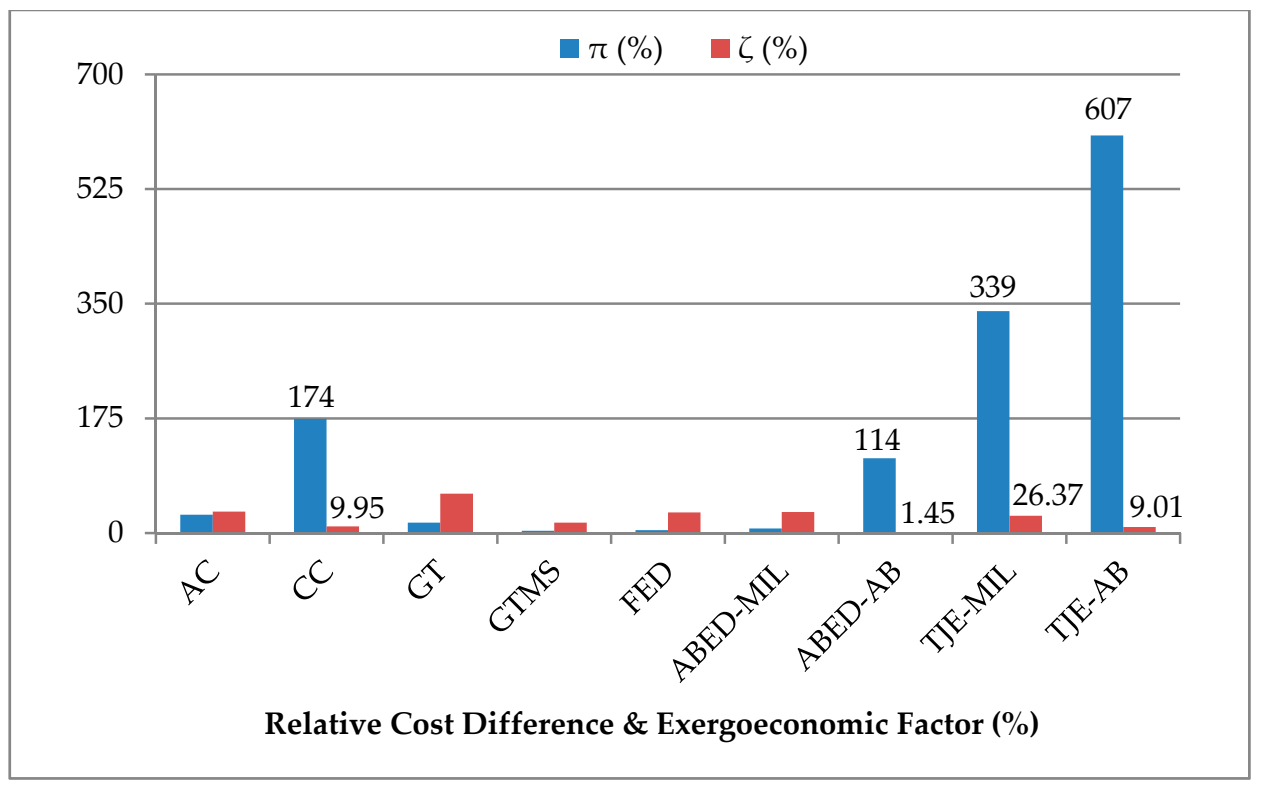

Figure 8. Relative cost difference $(\pi)$ and exergoeconomic factor $(\zeta)$ with $\mathrm{H}_{2}$ fuel usage.

With respect to Table 12, the ultimate unit fuel cost rate was calculated in the AC section, which had a rate of $136 \$ / G J$, while it was reckoned at $40.81 \$ / G J$ for the entire engine. Moreover, the AC section had the ultimate unit product cost with a rate of $174 \$ / G J$, while it was calculated to be $179 \$ / G J$ for the whole engine. The utmost $\dot{C}_{C}$ and the $\pi$ were determined to be $1245 \$ / \mathrm{h}$ and $174 \%$ in the CC section, seriatim, while they were reckoned at $1845 \$ / h$ and $339 \%$ for the whole engine. Therewithal, the CC section had the minimum $\zeta$ with $9.95 \%$.

With respect to Table 13, the ultimate unit fuel cost rate was calculated in the AC section, which had a rate of $136 \$ / G J$, while it was reckoned at $40.81 \$ / G J$ for the entire engine. Moreover, the AC section had the ultimate unit product cost with a rate of $174 \$ / G$, while it was calculated to be288 $\$ / G J$ for the entire engine. The ultimate $\pi$ was assigned in the CC and ABED sections as $174 \%$ and $114 \%$, seriatim. The ultimate $\dot{C}_{C}$ was determined $4488 \$ / \mathrm{h}$ in the ABED section, while it was reckoned at $6676 \$ / \mathrm{h}$ for the whole engine. At the same time, ABED had the minimum $\zeta$ with $1.45 \%$.

The comparative consequences of this research according to Figure 9 with the J85-GE-CAN-15 TJE research [49] are discussed as follows: 


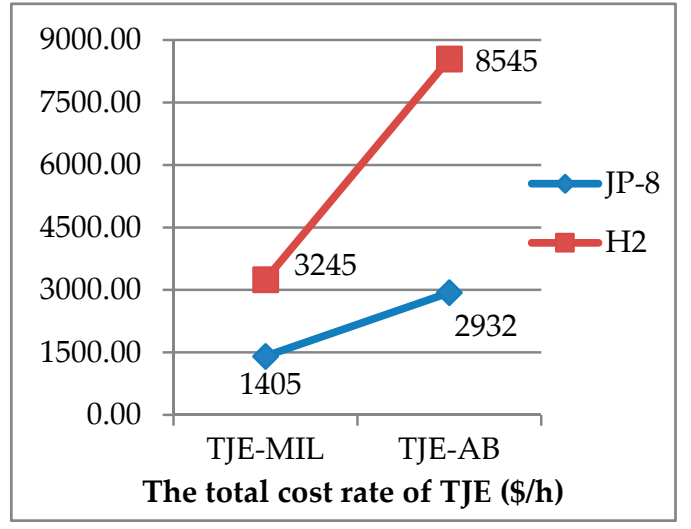

(a)

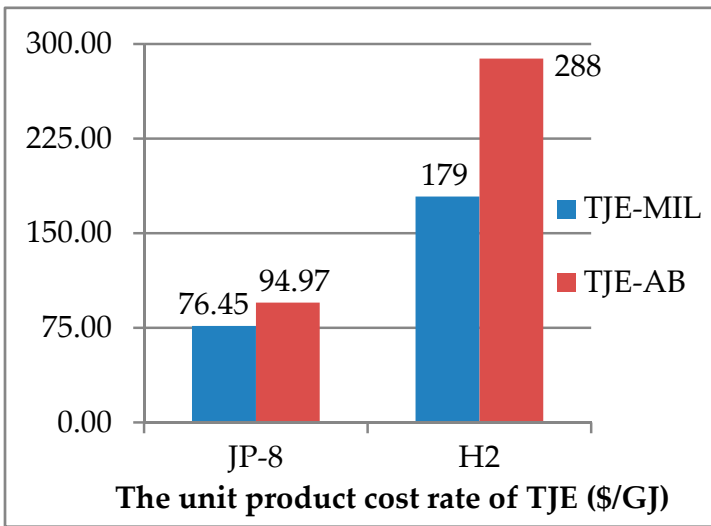

(b)

Figure 9. (a) The TJE's total cost rate; (b) The TJE's unit product cost rate.

The $\dot{C}_{F}$, the $c_{\operatorname{Pr}}$ and the $\dot{C}_{C}$ of J85-GE-CAN-15 TJE engine were determined to be $1482 \$ / \mathrm{h}, 121 \$ / \mathrm{GJ}$ and $1040 \$ / \mathrm{h}$ for MIL PM, respectively, while they were reckoned as $4079 \$ / \mathrm{h}, 133 \$ / \mathrm{GJ}$ and $3150 \$ / \mathrm{h}$ for AB PM with kerosene fuel utilization. Moreover, while the SEF were calculated to be1.42 and 1.29 for the MIL and AB PM, seriatim, the SCI were reckoned at 85.26 and $103 \$ / G J$. As per Figure 9, the results indicate that the J85-GE-5H TJE for the present study is more cost effective than the J85-GE-CAN-15 TJE.

From another research perspective, as per [52], the $\dot{C}_{F}$, the $c_{\operatorname{Pr}}$ and the $\dot{C}_{C}$ of the (J69-T-25A) TJE engine were determined to be $1144 \$ / \mathrm{h}, 355 \$ / \mathrm{GJ}$ and $980 \$ / \mathrm{h}$, respectively, with $\mathrm{H}_{2}$ fuel use. Although the exergetic efficiency of the J69 TJE was less than the one in this study, the J85-GE-5H TJE's $\dot{C}_{T J E}$ was reckoned higher than the J69 TJE due to the higher rates of the $\dot{C}_{F}$ and the $\dot{Z}^{\text {TIC }}$ comparatively. In accordance with Table 9, the outcomes of the exergoeconomic analysis are confirmed with the results of the advanced exergoeconomic analysis. While the advanced investment costs are demonstrated in Table 14, the exergoeconomic destruction costs are indicated in Table 15 for JP-8 usage.

Table 14. Results for advanced investment costs for kerosene use.

\begin{tabular}{|c|c|c|c|c|c|c|c|c|c|}
\hline SEC. & $\dot{Z}^{T I C}(\$ / h)$ & $\dot{Z}^{U N}(\$ / \mathrm{h})$ & $\dot{Z}^{A V}(\$ / \mathrm{h})$ & $\dot{Z}^{E X}(\$ / \mathrm{h})$ & $\dot{Z}^{E N}(\$ / \mathrm{h})$ & $\dot{Z}^{\text {UNEN }}(\$ / \mathrm{h})$ & $\dot{Z}^{U N E X}(\$ / \mathrm{h})$ & $\dot{Z}^{A V E N}(\$ / \mathrm{h})$ & $\dot{Z}^{A V E X}(\$ / h)$ \\
\hline $\mathrm{AC}$ & 209 & 178 & 31.38 & 31.34 & 178 & 151 & 26.64 & 26.68 & 4.70 \\
\hline $\mathrm{CC}$ & 138 & 110 & 27.53 & 12.62 & 125 & 100 & 10.10 & 25.01 & 2.52 \\
\hline GT & 193 & 173 & 19.27 & 12.00 & 181 & 163 & 10.80 & 18.07 & 1.20 \\
\hline FED & 41.29 & 35.10 & 6.19 & 5.12 & 36.17 & 30.74 & 4.35 & 5.43 & 0.77 \\
\hline ABED-MIL & 66.07 & 52.85 & 13.21 & 9.05 & 57.02 & 45.61 & 7.24 & 11.40 & 1.81 \\
\hline ABED-AB & 66.07 & 52.85 & 13.21 & 11.15 & 54.92 & 43.94 & 8.92 & 10.98 & 2.23 \\
\hline GTMS & 13.76 & 12.39 & 1.38 & 0.94 & 12.82 & 11.54 & 0.85 & 1.28 & 0.09 \\
\hline TJE-MIL & 661 & 562 & 99 & 65 & 596 & 506 & 55.33 & 89.21 & 9.75 \\
\hline TJE-AB & 661 & 562 & 99 & 97 & 564 & 479 & 82.36 & 84.45 & 14.51 \\
\hline
\end{tabular}

Table 15. Results for advanced exergy destruction costs for kerosene utilization.

\begin{tabular}{|c|c|c|c|c|c|c|c|c|c|}
\hline SEC. & $\dot{C_{D}}(\$ / \mathrm{h})$ & $\dot{C}_{D}^{U N}(\$ / \mathrm{h})$ & $\dot{C}_{D}^{A V}(\$ / \mathrm{h})$ & $\dot{C}_{D}^{E X}(\$ / \mathrm{h})$ & $\dot{C}_{D}^{E N}(\$ / h)$ & $\dot{C}_{D}^{U N E N}(\$ / \mathrm{h})$ & $\dot{C}_{D}^{U N E X}(\$ / \mathrm{h})$ & $\dot{C}_{D}^{A V E N}(\$ / \mathrm{h})$ & $\dot{C}_{D}^{A V E X}(\$ / \mathrm{h})$ \\
\hline $\mathrm{AC}$ & 189 & 154 & 34.36 & 28.28 & 160 & 130 & 24.00 & 30.08 & 4.28 \\
\hline $\mathrm{CC}$ & 338 & 329 & 9.34 & 31.04 & 307 & 299 & 30.31 & 8.61 & 0.74 \\
\hline GT & 32.12 & 19.48 & 12.64 & 2.00 & 30.12 & 18.15 & 1.33 & 11.97 & 0.67 \\
\hline FED & 34.43 & 22.51 & 11.92 & 4.27 & 30.16 & 19.62 & 2.89 & 10.54 & 1.38 \\
\hline ABED-MIL & 42.06 & 23.35 & 18.70 & 5.76 & 36.30 & 19.97 & 3.38 & 16.33 & 2.38 \\
\hline TJE-MIL & 515 & 380 & 134 & 146 & 369 & 343 & 37.48 & 26.36 & 108 \\
\hline TJE-AB & 1886 & 1127 & 759 & 788 & 1098 & 962 & 165 & 136 & 623 \\
\hline
\end{tabular}


With respect to Table 3 , the $\dot{Z}_{T J E}^{T I C}$ of TJE was $661 \$ / \mathrm{h}$ for both PM with kerosene use. The major fragments of this rate were determined to be $209 \$ / \mathrm{h}$ in the AC and $193 \$ / \mathrm{h}$ in the GT sections. As per Table 14 for JP-8 utilization, $\dot{Z}_{T J E}^{A V}$ and $\dot{Z}_{T J E}^{U N}$ were calculated within the same rate as $98.96 \$ / \mathrm{h}$ and $562 \$ / \mathrm{h}$ for both PM, seriatim. The maximum $\dot{Z}^{A V}$, determined in the AC, was 31.38\$/h. The ultimate $\dot{Z}^{U N}$, found out in the AC, was $178 \$ / \mathrm{h}$, since it had the highest unavoidable equipment cost in the entire engine. The $\dot{Z}_{A C}^{U N}$ of the AC was the aggregate of $\dot{Z}_{A C}^{U N E N}$ with a rate of $151 \$ / \mathrm{h}$ and $\dot{Z}_{A C}^{U N E X}$ with a rate of $26.64 \$ / \mathrm{h}$.

On the other hand, the utmost endogenous investment cost $\dot{Z}^{E N}$, occurring in the GT section, was $181 \$ / \mathrm{h}$. The percentage of $\dot{Z}_{G T}^{E N}$ was $31.55 \%$ of the $\dot{Z}_{T J E}^{E N}(564 \$ / \mathrm{h})$ and $26.92 \%$ of the $\dot{Z}_{T J E}^{T I C}$. The great $\dot{Z}^{E N}$ was computed because of major $\dot{E} x_{D}^{E N}$. Therefore, the exogenous investment cost $\dot{Z}^{E X}$ was reckoned to be less than the $\dot{Z}^{E N}$. While the TJE had $\dot{Z}_{T J E}^{E N}$ with rates of 596 and 564 \$/h for the MIL and AB PM, seriatim, it had $\dot{Z}_{T J E}^{E X}$ within rates of 65.08 and $96.87 \$ / \mathrm{h}$. The more exergy destruction and loss occur in the engine, the more endogenous investment cost becomes. The major fragments of the $\dot{Z}^{E X}$ indicated in Table 14 were assigned 31.34 \$/h in the AC and 12.62 \$/h in the CC sections. The results show that the AC had a noticeable impact on the CC section, while the CC section had a similar impact on the AC section. Additionally, the ultimate $\dot{Z}^{A V E X}$ was calculated to be 4.70 and $2.52 \$ / h$ in the AC and CC sections, seriatim, while the $\dot{Z}^{A V E N}$ was calculated to be $26.68 \$ / \mathrm{h}$ and $25.01 \mathrm{\$} / \mathrm{h}$.

In accordance with Tables A3 and A4, the advanced exergoeconomic cost rates are displayed in Table 15. The TJE's avoidable exergy demolition cost rates $\dot{C}_{D}^{A V}$ were reckoned at $134 \$ / \mathrm{h}$ and $759 \$ / \mathrm{h}$ for MIL and AB PM, seriatim. The maximum part of the $\dot{C}_{D}^{A V}$ was determined in the AC as $34.36 \$ / \mathrm{h}$ for the MIL PM, while it was computed in the ABED with a rate of $208 \$ / h$ for the AB PM. The ultimate unavoidable exergy destruction cost rate $\dot{C}_{D}^{U N}$ was found out in the CC with a value of 329 \$/h for MIL PM, while it was reckoned in the ABED with a rate of $1152 \$ / \mathrm{h}$ for AB PM. The $\dot{C}_{D}$ AN division of the CC was the aggregate of $\dot{C}_{D}^{U N E X}$ and $\dot{C}_{D}^{U N E N}$ with rates of 30.31 and $299 \$ / \mathrm{h}$, seriatim, for MIL PM, whereas it was the aggregate of 96.85 and $955 \$ / \mathrm{h}$ for AB PM. The unavoidable cost rates cannot be reduced because of manufacturing restraints.

On the other hand, the ultimate endogenous exergy demolition cost $\dot{C}_{D}^{E N}$, occurring in the CC, was $307 \$ / \mathrm{h}$. The ultimate $\dot{C}_{D}^{E N}$ was reckoned because of the combustion process. Hence, the exogenous exergy demolition cost $\dot{C}_{D}^{E X}$ was computed less than the $\dot{C}_{D}^{E N}$. While the TJE had $\dot{C}_{D, T J E}^{E N}$ with rates of 369 and 1098 \$/h for the MIL and AB PM, seriatim, the TJE engine had $\dot{C}_{D, T J E}^{E X}$ within rates of 146 and $788 \$ / \mathrm{h}$. The maximum division of the $\dot{C}_{D}^{E X}$ was determined in the CC with a rate of $146 \$ / \mathrm{h}$ for the MIL PM, whereas it was computed in the ABED with a rate of $788 \$ / \mathrm{h}$ for the AB PM. The $\dot{C}_{D}^{E X}$ came about in the related section because of the irreversible processes happened in the other sections. The mutual coactions among the engine sections can be figured out by breaking down the destruction cost rates into the exogenous divisions. The utmost avoidable-exogenous exergy destruction cost rate $\dot{C}_{D} A V E X$ was calculated in the AC with a value of 4.28 \$/h for MIL PM, while it was reckoned in the ABED with a rate of $33.79 \$ / \mathrm{h}$ for the AB PM. At the same time, the ultimate avoidable-endogenous exergy demolition cost rate $\dot{C}_{D}^{A V E N}$ was reckoned in the AC with a value of 30.08 \$/h for MIL PM, while it was reckoned in the $A B E D$ with a rate of $174 \$ / \mathrm{h}$ for the $A B$ PM. As per the outcomes, the $\dot{C}_{D}^{A V E X}$ could be reduced by implementing structural ameliorations to the entire system. The $\dot{C}_{D}^{A V E N}$ part could be mitigated by ameliorating the yield of the investigated section. When taking into account the usage of $\mathrm{H}_{2}$, the advanced investment costs are demonstrated in Table 16 and the exergoeconomic destruction costs are displayed in Table 17. 
Table 16. Results for advanced investment costs for $\mathrm{H}_{2}$ utilization.

\begin{tabular}{cccccccccc}
\hline SEC. & $\dot{Z}^{\text {TIC }} \mathbf{( \$ / \mathbf { h } )}$ & $\dot{Z}^{U N} \mathbf{( \$ / \mathbf { h } )}$ & $\dot{Z}^{A V} \mathbf{( \$ / \mathbf { h } )}$ & $\dot{Z}^{E X} \mathbf{( \$ / \mathbf { h } )}$ & $\dot{Z}^{E N} \mathbf{( \$ / h )}$ & $\dot{Z}^{U N E N} \mathbf{( \$ / h )}$ & $\dot{Z}^{U N E X} \mathbf{( \$ / h )}$ & $\dot{Z}^{A V E N} \mathbf{( \$ / h )}$ & $\dot{Z}^{\text {AVEX }} \mathbf{( \$ / \mathbf { h } )}$ \\
\hline AC & 209 & 178 & 31.38 & 28.38 & 181 & 154 & 24.12 & 27.12 & 4.26 \\
CC & 138 & 110 & 27.53 & 13.98 & 124 & 98.93 & 11.18 & 24.73 & 2.80 \\
GT & 193 & 173 & 19.27 & 30.61 & 162 & 146 & 27.55 & 16.21 & 3.06 \\
FED & 41.29 & 35.10 & 6.19 & 4.02 & 37.27 & 31.68 & 3.42 & 5.59 & 0.60 \\
ABED-MIL & 66.07 & 52.85 & 13.21 & 8.70 & 57.37 & 45.89 & 6.96 & 11.47 & 1.74 \\
ABED-AB & 66.07 & 52.85 & 13.21 & 12.31 & 53.76 & 43.01 & 9.85 & 10.75 & 2.46 \\
GTMS & 13.76 & 12.39 & 1.38 & 1.26 & 12.50 & 11.25 & 1.13 & 1.25 & 0.13 \\
TJE-MIL & 661 & 562 & 99 & 70.64 & 590 & 502 & 60.05 & 88.38 & 10.58 \\
TJE-AB & 661 & 562 & 99 & 71.42 & 589 & 501 & 60.72 & 88.27 & 10.70 \\
\hline
\end{tabular}

Table 17. Results for advanced exergy destruction costs of TJE and sections for $\mathrm{H}_{2}$ utilization.

\begin{tabular}{cccccccccc}
\hline SEC. & $\dot{C}_{D}(\mathbf{\$} / \mathbf{h})$ & $\dot{C}_{D}^{U N}(\mathbf{\$} / \mathbf{h})$ & $\dot{C}_{D}^{A V}(\mathbf{\$} / \mathbf{h})$ & $\dot{C}_{D}^{E X}(\$ / \mathbf{h})$ & $\dot{C}_{D}^{E N}(\$ / \mathbf{h})$ & $\dot{C}_{D}^{U N E N}(\$ / \mathbf{h})$ & $\dot{C}_{D}^{U N E X}(\mathbf{\$} / \mathbf{h})$ & $\dot{C}_{D}^{A V E N}(\$ / \mathbf{h})$ & $\dot{C}_{D}^{A V E X}(\mathbf{\$} / \mathbf{h})$ \\
\hline AC & 433 & 354 & 78.86 & 58.77 & 374 & 305 & 49.61 & 69.70 & 9.16 \\
CC & 1245 & 1201 & 44.12 & 126 & 1119 & 1080 & 121 & 38.94 & 5.18 \\
GT & 129 & 86.98 & 41.53 & 20.41 & 108 & 71.22 & 15.76 & 36.88 & 4.65 \\
FED & 89.97 & 56.68 & 33.29 & 8.76 & 81.21 & 50.35 & 6.33 & 30.86 & 2.43 \\
ABED-MIL & 139 & 76.60 & 62.60 & 18.33 & 121 & 64.43 & 12.17 & 56.44 & 6.16 \\
ABED-AB & 4488 & 3709 & 779 & 840 & 3648 & 3007 & 703 & 641 & 138 \\
GTMS & 73.37 & 41.46 & 31.91 & 6.72 & 66.65 & 37.64 & 3.82 & 29.01 & 2.90 \\
TJE-MIL & 1845 & 1398 & 447 & 483 & 1362 & 1249 & 149 & 113 & 334 \\
TJE-AB & 6676 & 4175 & 2501 & 2599 & 4077 & 3499 & 676 & 578 & 1923 \\
\hline
\end{tabular}

According to Table 3, the $\dot{Z}_{T J E}^{T I C}$ of TJE was $661 \$ / \mathrm{h}$ for both modes with $\mathrm{H}_{2}$ use. The great portion of this rate were determined to be $209 \$ / \mathrm{h}$ in the AC and $193 \$ / \mathrm{h}$ in the GT sections; the minor portions were found to be $13.76 \$ / \mathrm{h}$ in the GTMS and $41.29 \$ / \mathrm{h}$ in the FED sections. As per Table 16 for $\mathrm{H}_{2}$ usage, $\dot{Z}_{T J E}^{A V}$ and $\dot{Z}_{T J E}^{U N}$ were calculated within the same rates as $98.96 \$ / \mathrm{h}$ and $562 \$ / \mathrm{h}$ for both PM, seriatim. The maximum $\dot{Z}^{A V}$ was found out in the $\mathrm{AC}$ with a rate of $31.38 \$ / \mathrm{h}$, while the utmost $\dot{Z}^{U N}$ was determined in the $A C$ with a value of $178 \$ / \mathrm{h}$. The $\dot{Z}_{A C}^{U N}$ of the $A C$ was the aggregate of $\dot{Z}_{A C}^{\text {UNEN }}$ with a rate of $154 \$ / \mathrm{h}$ and $\dot{Z}_{A C}^{U N E X}$ with a rate of $24.12 \$ / \mathrm{h}$. The unavoidable divisions cannot be mitigated on account of technological restraints. On the other hand, the utmost $\dot{Z}_{G T}^{E N}$ computed in the AC to be $181 \$ / \mathrm{h}$. The higher the $\dot{E} x_{D, n}^{E N}$ occurred, the more $\dot{Z}^{U N}$ became. Hence, the $\dot{Z}^{E X}$ was determined less. While the TJE had $\dot{Z}_{T J E}^{E N}$ with rates of 596 and $564 \$ / \mathrm{h}$ for both PM, seriatim, the TJE engine had $\dot{Z}_{T J E}^{E X}$ within the rates of 65.08 and $96.87 \$ / \mathrm{h}$. The major fragments of the $\dot{Z}^{E X}$ indicated in Table 16 were assigned $30.61 \$ / \mathrm{h}$ in the GT and $28.38 \$ / \mathrm{h}$ in the AC sections. The results show that the GT had a noticeable impact on the AC section, while the AC had a similar effect on the GT section. In addition, the $\dot{Z}^{A V E X}$ rates were calculated to be 4.26 and $2.80 \$ / h$ in the AC and CC sections, seriatim, while the $\dot{Z}^{A V E N}$ rates were reckoned at 27.12 and $24.73 \$ / \mathrm{h}$.

In accordance with Tables $A 5$ and $\mathrm{A} 6$, the $\dot{C}_{D}$ were demonstrated in Table 17. The TJE's $\dot{C}_{D}^{A V}$ were 447 and $2501 \$ / \mathrm{h}$ for MIL and AB PM, seriatim. The maximum part of the $\dot{C}_{D}^{A V}$ was determined in the AC with a rate of $78.86 \$ / \mathrm{h}$ for the MIL PM, whereas it was computed in the ABED with a rate of $779 \$ / \mathrm{h}$ for the AB PM. The ultimate $\dot{C}_{D}^{U N}$ in the CC was found to have a value of $1201 \$ / \mathrm{h}$ for MIL $\mathrm{PM}$, while it was reckoned in the ABED with a rate of $3709 \$ / \mathrm{h}$ for AB PM. The $\dot{C}_{D}^{U N}$ fragment of the CC was the aggregate of $\dot{C}_{D}^{U N E X}$ with a rate of $121.27 \$ / \mathrm{h}$ and $\dot{C}_{D}^{U N E N}$ with a rate of $1080 \$ / \mathrm{h}$ for MIL PM, whereas it was the aggregate of $\dot{C}_{D}^{U N E X}$ with a rate of $703 \$ / \mathrm{h}$ and $\dot{C}_{D}^{U N E N}$ with a rate of $3007 \$ / \mathrm{h}$ in ABED for AB PM. 
On the other hand, the ultimate $\dot{C}_{D}^{E N}$, determined in the CC, was $1119 \$ / \mathrm{h}$. The TJE had $\dot{C}_{D, T J E}^{E N}$ rates of 1362 and $4077 \$ / \mathrm{h}$ for the MIL and AB PM, seriatim, while it had $\dot{C}_{D, T J E}^{E X}$ rates of 483 and $2599 \$ / \mathrm{h}$. The maximum fragment of the $\dot{C}_{D}^{E X}$ was determined in the CC with a rate of $126 \$ / \mathrm{h}$ for the MIL PM, while it was computed in the ABED with a rate of $840 \$ / \mathrm{h}$ for the AB PM. The ultimate $\dot{C}_{D}^{A V E X}$ was calculated in the AC with a value of $9.16 \$ / \mathrm{h}$ for MIL PM, while it was reckoned in the ABED to be a rate of $138 \$ / \mathrm{h}$ for the AB PM. At the same time, the maximum $\dot{C}_{D}^{A V E N}$ was reckoned in the $A C$ as $69.70 \$ / h$ for MIL PM, while it was reckoned in the ABED as $641 \$ / h$ for the AB PM. According to the outcomes, the $\dot{C}_{D}^{A V E X}$ rates could be mitigated by increasing the whole of the TJE's yield. The $\dot{C}_{D}^{A V E N}$ rates could be minified by ameliorating the efficiency of the investigated section.

\section{Conclusions}

J85-GE-5H TJE was evaluated completely considering exergoeconomic and advanced exergoeconomic analyses with kerosene and hydrogen fuels usage. Primarily, sustainability, exergoeconomic and advanced exergoeconomic analyses of the TJE were fulfilled utilizing kerosene fuel with respect to real engine working circumstances. The aforementioned analyses were then perused parametrically in terms of using $\mathrm{H}_{2}$ fuel. After all, the outcomes reckoned for both fuel uses were collated in terms of cost effectiveness assessment of the TJE. The main conspicuous sequels related to the current research were stated below:

- The $\dot{C}_{F}$ rates were calculated to be 745 and $2271 \$ / \mathrm{h}$ for the MIL and AB PM with kerosene use, seriatim, while they were obtained as 2585 and $7885 \$ / \mathrm{h}$ with $\mathrm{H}_{2}$ use.

- $\quad$ The $\dot{C}_{D}$ rates with JP-8 were determined 515 \$/h for the MIL PM and $1886 \$ / h$ for the AB PM. By considering the use of hydrogen, the $\dot{C}_{D}$ for the MIL PM was $1845 \$ / \mathrm{h}$, whereas it was $6676 \$ / \mathrm{h}$ for the AB PM.

- The $c_{\text {Pr }}$ rates were determined as $76.45 \$ / G J$ and $94.97 \$ / G J$ with kerosene use, seriatim, while they were computed as $179 \$ / \mathrm{GJ}$ and 288 \$/GJ with $\mathrm{H}_{2}$ use.

- The $\dot{C}_{T J E}$ rates were reckoned to be $1405 \$ / \mathrm{h}$ for the MIL PM and 2932 \$/h for the AB PM. By considering the usage of hydrogen, the $\dot{C}_{T J E}$ were $3245 \$ / \mathrm{h}$ and $8545 \$ / \mathrm{h}$, seriatim.

- The EBAP values were computed to be $356 \$ / \mathrm{h}$ and $1565 \$ / \mathrm{h}$ for the MIL and AB PM with kerosene use, seriatim, while they were reckoned as $1317 \$ / \mathrm{h}$ and $5652 \$ / \mathrm{h}$ with $\mathrm{H}_{2}$ use.

- The $\zeta$ rates were computed as $56.20 \%$ and $25.95 \%$ for the MIL and AB PM with kerosene use, seriatim. By taking into account the use of $\mathrm{H}_{2}$, the $\zeta$ were $26.37 \%$ and $9.01 \%$.

- The $\pi$ rates were calculated to be $512 \%$ for the MIL PM and $660 \%$ for the AB PM. By considering the use of hydrogen, the $\pi$ were $339 \%$ and $607 \%$, seriatim.

- The SEF values were determined to be 1.45 and 1.20 for the MIL and AB PM with kerosene use, seriatim, while they were calculated 1.40 and 1.18 with $\mathrm{H}_{2}$ use.

- The SCI values were determined to be 52.86 and 78.87 \$/GJ for the MIL and AB PM, seriatim, whereas they were reckoned 128 and $244 \$$ GJ with $\mathrm{H}_{2}$ use.

- The $\dot{C}_{D}^{U N}$ rates were calculated as 380 and 1127 \$/h for MIL and AB PM with kerosene use, seriatim, while they were determined as 1298 and $4175 \$ / \mathrm{h}$ with $\mathrm{H}_{2}$ use. Moreover, the $\dot{C}_{D}^{U N E N}$ rate had the highest $\dot{C}_{D}$ for both fuel utilizations. Hence, the tract has low amelioration aptness.

- The $\dot{Z}_{T J E}^{U N}$ and the $\dot{Z}_{T J E}^{A V}$ rates were reckoned with values of 562 and $98.96 \$ / \mathrm{h}$, seriatim, for both fuel uses.

- The $\dot{Z}_{T J E}^{E N}$ rates were computed as 596 and 564 \$/h for MIL and AB PM with kerosene use, seriatim, while they were reckoned as 590 and 589 \$/h with $\mathrm{H}_{2}$ use. 
- The $\dot{Z}_{T J E}^{E X}$ rates were calculated 65.08 and $96.87 \$ / h$ for MIL and AB PM with kerosene use, seriatim, while they were reckoned to be 70.64 and $71.42 \$ / \mathrm{h}$ with $\mathrm{H}_{2}$ use.

- The $\dot{C}_{D}^{E N}$ rates were computed as 369 and $1098 \$ / \mathrm{h}$ for MIL and AB PM with kerosene use, seriatim, whereas they were determined as 1362 and $4077 \$ / h$ with $\mathrm{H}_{2}$ use.

- The $\dot{C}_{D}^{E X}$ rates were computed to be 146 and $788 \$ / \mathrm{h}$ for MIL and AB PM with kerosene use, seriatim, while they were determined as 483 and $2599 \$ / \mathrm{h}$ with $\mathrm{H}_{2}$ use.

- As the $\dot{C}_{D}^{E N}$ rates were computed higher than the $\dot{C}_{D}^{E X}$ rates, the coactions between the sections were low.

- The $\dot{C}_{D}^{A V}$ rates were computed as 134 and 759 \$/h for MIL and AB PM with kerosene use, seriatim, while they were determined as 447 and $2501 \$ / \mathrm{h}$ with $\mathrm{H}_{2}$ use. Moreover, the $\dot{C}_{D}^{A V E X}$ had a smaller $\dot{C}_{D}$ rate than the $\dot{C}_{D}^{A V E N}$ cost rate in the whole tract not only for kerosene use but also for $\mathrm{H}_{2}$ use.

Between the system sections, the CC and ABED had the maximum $\dot{C}_{D}, \dot{C}_{D}^{U N}, \mathrm{SCI}, \pi$ and EBAP rates for both fuel usages, whereas they had the minimum $\zeta$ and SEF rates. These results demonstrated that the primary factor bringing about an increase in the cost rates was the high demolition cost values of the $C C$ and $A B E D$ sections because of the imperfections that happened in the combustion process. Meanwhile, the utmost avoidable investment costs were determined in the AC, CC and GT sections, whereas the utmost avoidable exergy destruction costs were reckoned in the ABED, $\mathrm{AC}$ and $\mathrm{CC}$ sections because of the relatively great exergy destructions rates. When the analyses are examined in terms of the internal state of the section, it was revealed that the potential for improvement depended mostly on sections. Hence, the endogenous demolition cost rate was larger than the exogenous demolition cost rate. The results were also similar for the cost rates of investment in terms of advanced analysis. The aforementioned analyses indicated that the sections were in the boundary of thermodynamic restraints as per the $\dot{Z}^{U N E N}$ and the $\dot{C}_{D}^{U N E N}$ rates and had to be produced to obtain better performance not only in thermodynamic efficiency but also in cost effectiveness. Therefore, the researchers have been studying to enhance the performance of TJE by implementing innovations such as three-dimensional (3D) print manufacturing technologies, which lessen the labor, material and development cost rates drastically.

Consequently, the engine operated less cost effective with the use of $\mathrm{H}_{2}$ because of the increase in $\dot{C}_{D}$. Moreover, it was less sustainable due to the lower efficiency. Although the renewable energy sources will take the place of oil resources in the future, there has to be done to pave the way of production technologies to alter the challenges both in efficiency and cost effectiveness in gas turbine systems.

Author Contributions: Conceptualization, B.Y. and A.H.; methodology, B.Y. and A.H.; software, B.Y. and H.G.; validation, B.Y. and A.H.; formal analysis, B.Y. and A.H.; investigation, B.Y. and A.H.; resources, B.Y. and H.G.; data curation, H.G.; writing-original draft preparation, B.Y.; writing-review and editing, B.Y. and A.H. All authors have read and agreed to the published version of the manuscript.

Funding: This study received no external funding.

Acknowledgments: The authors are very grateful to the three reviewers and Assistant Editor for their constructive and valuable suggestions, which helped increase the quality of the paper.

Conflicts of Interest: The authors declare no conflict of interest.

\section{Nomenclature}

$\begin{array}{ll}A C \dot{C} & \text { yearly capital cost rate }(\$ / \mathrm{yr}) \\ c & \text { unit exergy flow cost }(\$ / \mathrm{GJ}) \\ c_{p} & \text { specific heat capacity }(\mathrm{kJ} /(\mathrm{kg} \cdot \mathrm{K})) \\ \dot{C} & \text { exergy flow cost rate }(\$ / \mathrm{h})\end{array}$




\begin{tabular}{|c|c|}
\hline$C R F$ & cost recovery factor (-) \\
\hline$\dot{E}$ & energy rate $(\mathrm{kW}$ or $\mathrm{GJ} / \mathrm{h})$ \\
\hline$\dot{E} B A P$ & economic benefit of amelioration potential rate $(\$ / h)$ \\
\hline$\dot{E} x$ & exergy rate $(\mathrm{kW}$ or $\mathrm{GJ} / \mathrm{h})$ \\
\hline$F \dot{C}$ & yearly fuel cost rate $(\$ / y r)$ \\
\hline$F P$ & fuel price $(\$ / \mathrm{kg})$ \\
\hline$i$ & interest rate $(\%)$ \\
\hline$L H V$ & lower heating value of fuel $(\mathrm{kJ} / \mathrm{kg})$ \\
\hline$\dot{m}$ & mass flow rate $(\mathrm{kg} / \mathrm{s})$ \\
\hline$n$ & lifetime (yr) \\
\hline$O M \dot{C}$ & yearly operation and maintenance cost $(\$ / y r)$ \\
\hline$P$ & pressure $(\mathrm{kPa})$ \\
\hline$P V F$ & present value factor (-) \\
\hline$P W$ & present value $(\$)$ \\
\hline$\dot{Q}$ & heat transfer rate $(\mathrm{kW}$ or $\mathrm{GJ} / \mathrm{h})$ \\
\hline$R C$ & $\begin{array}{l}\text { ratio of the purchase cost of the section to the } \\
\text { investment cost (\%) }\end{array}$ \\
\hline$S C I$ & sustainability cost index $(\$ / G J)$ \\
\hline SEF & sustainability effect factor (-) \\
\hline$S V$ & salvage value $(\$)$ \\
\hline$S V R$ & salvage value rate $(\%)$ \\
\hline$T$ & temperature $\left({ }^{\circ} \mathrm{C}\right.$ or $\left.\mathrm{K}\right)$ \\
\hline TIC & total investment cost $(\$)$ \\
\hline$V$ & velocity $(\mathrm{m} / \mathrm{s})$ \\
\hline$\dot{W}$ & work rate or power $(\mathrm{kW}$ or $\mathrm{GJ} / \mathrm{h})$ \\
\hline$\dot{Z}$ & hourly investment cost rate $(\$ / \mathrm{h})$ \\
\hline \multicolumn{2}{|l|}{ Greek Letters } \\
\hline$\psi$ & exergy (second law) yield (\%) \\
\hline$\tau$ & yearly operation hour (h/yr) \\
\hline$\pi$ & relative cost difference (\%) \\
\hline$\zeta$ & exergoeconomic factor (\%) \\
\hline \multicolumn{2}{|l|}{ Subscripts } \\
\hline$A B E D$ & afterburner exhaust duct \\
\hline$A C$ & air compressor \\
\hline C & consumption \\
\hline CC & combustion chamber \\
\hline$D$ & destroyed, destruction \\
\hline$F$ & fuel \\
\hline FED & forward exhaust duct \\
\hline GT & gas turbine \\
\hline GTMS & gas turbine mechanic shaft \\
\hline in & inlet \\
\hline$k n$ & kinetic exergy \\
\hline$L$ & losses \\
\hline$n$ & $n$-th section \\
\hline out & outlet \\
\hline$P$ & pressure \\
\hline $\operatorname{Pr}$ & product \\
\hline$T$ & temperature \\
\hline TJE & turbojet engine \\
\hline 0 & reference state \\
\hline $1,2,3, \ldots 8,9,10$ & location numbers of sections \\
\hline
\end{tabular}




$\begin{array}{ll}\text { Superscripts } & \\ A V & \text { avoidable } \\ A V E N & \text { avoidable-endogenous } \\ A V E X & \text { avoidable-exogenous } \\ E N & \text { endogenous } \\ E X & \text { exogenous } \\ \text { IC } & \text { investment cost } \\ \text { OM } & \text { operation and maintenance cost } \\ \text { RL } & \text { real } \\ \text { UN } & \text { unavoidable } \\ \text { UNEN } & \text { unavoidable-endogenous } \\ \text { UNEX } & \text { unavoidable-exogenous } \\ T I C & \text { total investment cost } \\ \text { Abbreviations } & \\ A B & \text { afterburner } \\ A C & \text { air compressor } \\ A B E D & \text { afterburner exhaust duct } \\ C C & \text { combustion chamber } \\ C F C O & \text { continuous flow continuous open } \\ \text { FED } & \text { forward exhaust duct } \\ G T & \text { gas turbine } \\ G T M S & \text { gas turbine mechanic shaft } \\ M I L & \text { military } \\ P M & \text { process mode } \\ S C I & \text { sustainability cost index } \\ S E F & \text { sustainable effect factor } \\ S E C & \text { section } \\ S P E C O & \text { specific exergy cost method } \\ T J E & \text { turbojet engine } \\ & \end{array}$

\section{Appendix A}

Table A1. Values for energy rate, exergy rate, mass flowrate, pressure and specific heat capacity for the system sections for JP-8 fuel utilization (*: solely for Afterburner (AB) process mode) [63].

\begin{tabular}{cccccccc}
\hline State No. & Fluid Type & $\dot{m}(\mathbf{k g} / \mathbf{s})$ & $\boldsymbol{P ( \mathbf { k P a } )}$ & $\mathbf{T}(\mathbf{K})$ & $\boldsymbol{c}_{\boldsymbol{p}}(\mathbf{k J} / \mathbf{k g} \cdot \mathbf{K})$ & $\dot{\boldsymbol{E}}(\mathbf{k W})$ & $\dot{\boldsymbol{E}} \boldsymbol{x}(\mathbf{k W})$ \\
\hline 0 & Air & 0.00 & 101 & 288 & 1.00375 & 0.00 & 0.00 \\
1 & Air & 18.12 & 101 & 288 & 1.00375 & 0.00 & 0.00 \\
2 & Air & 18.12 & 719 & 572 & 1.04401 & 5583 & 4700 \\
2.1 & Air & 16.31 & 719 & 572 & 1.04401 & 5024 & 4230 \\
2.2 & Air & 1.81 & 719 & 572 & 1.04401 & 558 & 470 \\
2.3 & Air & 1.81 & 182 & 943 & 1.12946 & 1405 & 740 \\
2.4 & Air & 1.81 & 179 & 932 & 1.12735 & 1380 & 720 \\
2.5 & Air & 1.81 & 175 & 920 & 1.12477 & 1350 & 699 \\
$2.5 *$ & Air & 1.81 & 175 & 1,563 & 1.13501 & 2691 & 1714 \\
3 & Military fuel & 0.36 & 245 & 298 & - & 15,593 & 16,554 \\
4 & Combustion gas & 16.67 & 683 & 1177 & 1.23710 & 19,454 & 13,258 \\
5 & Combustion gas & 16.67 & 182 & 943 & 1.18586 & 13,811 & 7156 \\
6 & Combustion gas & 16.67 & 179 & 932 & 1.18345 & 13,568 & 6966 \\
7 & Combustion gas & 16.67 & 175 & 920 & 1.18055 & 13,277 & 6746 \\
$7 *$ & Combustion gas & 17.41 & 175 & 1,563 & 1.38960 & 32,784 & 20,164 \\
$10 *$ & Afterburner fuel & 0.74 & 245 & 298 & - & 31,972 & 33,941 \\
8 & Mechanical work & - & - & - & - & 5640 & 5640 \\
9 & Mechanical work & - & - & - & - & 5583 & 5583 \\
\hline
\end{tabular}


Table A2. Values for energy rate, exergy rate, mass flowrate, pressure and specific heat capacity for the system sections for $\mathrm{H}_{2}$ fuel utilization (*: solely for $\mathrm{AB}$ process mode) [63].

\begin{tabular}{cccccccc}
\hline State No. & Fluid Type & $\dot{m} \mathbf{( k g} / \mathbf{s})$ & $\boldsymbol{P ( \mathbf { k P a } )}$ & $\mathbf{T}(\mathbf{K})$ & $\boldsymbol{c}_{\boldsymbol{p}}(\mathbf{k J} / \mathbf{k g} \cdot \mathbf{K})$ & $\dot{\boldsymbol{E}}(\mathbf{k W})$ & $\dot{\boldsymbol{E}} \boldsymbol{x}(\mathbf{k W})$ \\
\hline 0 & Air & 0.00 & 101 & 288 & 1.00375 & 0.00 & 0.00 \\
1 & Air & 18.12 & 101 & 288 & 1.00375 & 0.00 & 0.00 \\
2 & Air & 18.12 & 719 & 572 & 1.04401 & 5583 & 4700 \\
2.1 & Air & 16.31 & 719 & 572 & 1.04401 & 5024 & 4230 \\
2.2 & Air & 1.81 & 719 & 572 & 1.04401 & 558 & 470 \\
2.3 & Air & 1.81 & 182 & 923 & 1.12550 & 1359 & 710 \\
2.4 & Air & 1.81 & 179 & 912 & 1.12319 & 1332 & 690 \\
2.5 & Air & 1.81 & 175 & 894 & 1.11934 & 1289 & 665 \\
$2.5 *$ & Air & 1.81 & 175 & 1532 & 1.14204 & 2647 & 1677 \\
3 & Military fuel & 0.13 & 245 & 298 & - & 15,593 & 17,594 \\
4 & Combustion gas & 16.44 & 683 & 1156 & 1.27884 & 19,550 & 13,349 \\
5 & Combustion gas & 16.44 & 182 & 923 & 1.22356 & 13,813 & 7059 \\
6 & Combustion gas & 16.44 & 179 & 912 & 1.22086 & 13,552 & 6857 \\
7 & Combustion gas & 16.44 & 175 & 894 & 1.21645 & 13,125 & 6551 \\
$7 *$ & Combustion gas & 16.71 & 175 & 1532 & 1.38537 & 30,629 & 18,853 \\
$10 *$ & Afterburner fuel & 0.27 & 245 & 298 & - & 31,972 & 36,075 \\
8 & Mechanical work & - & - & - & - & 5737 & 5737 \\
9 & Mechanical work & - & - & - & - & 5583 & 5583 \\
\hline
\end{tabular}

Table A3. Results for endogenous, exogenous, unavoidable and avoidable exergy demolition of the TJE and its sections for the MIL process mode for JP-8 utilization [63].

\begin{tabular}{|c|c|c|c|c|c|c|c|c|c|}
\hline SEC. & $\dot{E} x_{D}^{R L}(\mathrm{~kW})$ & $\dot{E} x_{D}^{U N}(\mathbf{k W})$ & $\dot{E} x_{D}^{A V}(\mathbf{k W})$ & $\dot{E} x_{D}^{E X}(\mathrm{~kW})$ & $\dot{E} x_{D}^{E N}(\mathbf{k W})$ & $\dot{E} x_{D}^{U N E N}(\mathbf{k W})$ & $\dot{E} x_{D}^{U N E X}(\mathbf{k W})$ & $\dot{E} x_{D}^{A V E N}(\mathbf{k W})$ & $\dot{E} x_{D}^{A V E X}(\mathbf{k W})$ \\
\hline $\mathrm{CC}$ & 7525 & 7318 & 208 & 690 & 6835 & 6644 & 674 & 191 & 16.34 \\
\hline FED & 209 & 137 & 72.50 & 25.98 & 183 & 119 & 17.59 & 64.11 & 8.39 \\
\hline ABED & 241 & 134 & 107 & 33.06 & 208 & 115 & 19.42 & 93.71 & 13.64 \\
\hline GTMS & 57.13 & 31.15 & 25.98 & 3.90 & 53.23 & 28.89 & 2.26 & 24.34 & 1.64 \\
\hline
\end{tabular}

Table A4. Results for endogenous, exogenous, unavoidable and avoidable exergy demolition of TJE and sections for the AB process mode for JP-8 utilization [63].

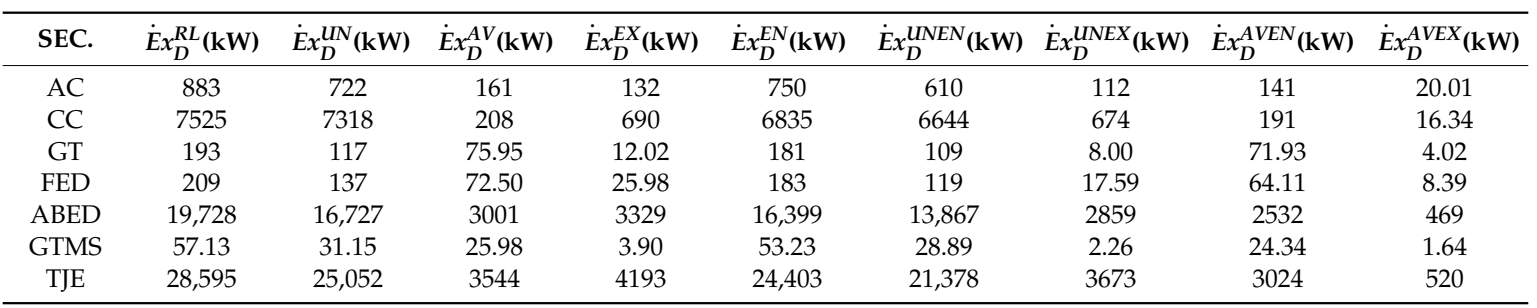

Table A5. Results for endogenous, exogenous, unavoidable and avoidable exergy demolition of TJE and sections in advanced exergy evaluation for the MIL process mode for $\mathrm{H}_{2}$ utilization [63].

\begin{tabular}{|c|c|c|c|c|c|c|c|c|c|}
\hline SEC. & $\dot{E} x_{D}^{R L}(\mathbf{k W})$ & $\dot{E} x_{D}^{U N}(\mathbf{k W})$ & $\dot{E} x_{D}^{A V}(\mathbf{k W})$ & $\dot{E} x_{D}^{E X}(\mathrm{~kW})$ & $\dot{E} x_{D}^{E N}(\mathbf{k W})$ & $\dot{E} x_{D}^{U N E N}(\mathbf{k W})$ & $\dot{E} x_{D}^{U N E X}(\mathbf{k W})$ & $\dot{E} x_{D}^{A V E N}(\mathbf{k W})$ & $\dot{E} x_{D}^{A V E X}(\mathbf{k W})$ \\
\hline $\mathrm{CC}$ & 8475 & 8174 & 300 & 861 & 7614 & 7349 & 826 & 265 & 35.24 \\
\hline FED & 223 & 140 & 82.43 & 21.69 & 201 & 125 & 15.67 & 76.41 & 6.02 \\
\hline ABED & 330 & 182 & 149 & 43.50 & 287 & 153 & 28.88 & 134 & 14.62 \\
\hline GTMS & 154 & 87.25 & 67.16 & 14.14 & 140 & 79.22 & 8.03 & 61.05 & 6.11 \\
\hline
\end{tabular}


Table A6. Results for endogenous, exogenous, unavoidable and avoidable exergy demolition of TJE and sections in advanced exergy evaluation for the $\mathrm{AB}$ process mode for $\mathrm{H}_{2}$ utilization [63].

\begin{tabular}{cccccccccc}
\hline SEC. & $\dot{E} x_{D}^{R L}(\mathbf{k W})$ & $\dot{E} x_{D}^{U N}(\mathbf{k W})$ & $\dot{E} x_{D}^{A V}(\mathbf{k W})$ & $\dot{E} x_{D}^{E X}(\mathbf{k W})$ & $\dot{E} x_{D}^{E N}(\mathbf{k W})$ & $\dot{E} x_{D}^{U N E N}(\mathbf{k W})$ & $\dot{E} x_{D}^{U N E X}(\mathbf{k W})$ & $\dot{E} x_{D}^{A V E N}(\mathbf{k W})$ & $\dot{E} x_{D}^{A V E X}(\mathbf{k W})$ \\
\hline AC & 883 & 722 & 161 & 120 & 763 & 621 & 101 & 142 & 18.66 \\
CC & 8475 & 8174 & 300 & 861 & 7614 & 7349 & 826 & 265 & 35.24 \\
GT & 313 & 212 & 101 & 49.74 & 263 & 174 & 38.40 & 89.87 & 11.34 \\
FED & 223 & 140 & 82.43 & 21.69 & 201 & 125 & 15.67 & 76.41 & 6.02 \\
ABED & 23,066 & 19,083 & 3,982 & 4297 & 18,769 & 15,469 & 3614 & 3299 & 68 \\
GTMS & 154 & 87.25 & 67.16 & 14.14 & 140 & 79.22 & 8.03 & 61.05 & 6.11 \\
TJE & 33,113 & 28,419 & 4694 & 5363 & 27,750 & 23,816 & 4603 & 3934 & 760 \\
\hline
\end{tabular}

\section{References}

1. Atılgan, R.; Turan, O.; Altuntas, O.; Aydin, H.; Synylo, K. Environmental impact assessment of a turboprop engine with the aid of exergy. Energy 2013, 58, 664-671. [CrossRef]

2. Cengel, Y.A.; Boles, M.A. Thermodynamics: An Engineering Approach, 8th ed.; Mc Graw-Hill Education: New York, NY, USA, 2014.

3. Turgut, E.T. Exergoeconomic Analysis of Aircraft Gas Turbine Engines. Ph.D. Thesis, Anadolu University, Eskisehir, Turkey, 2007.

4. Bejan, A.; Tsatsaronis, G.; Moran, M. Thermal Design and Optimization; Wiley: New York, NY, USA, 1996.

5. Lee, D.S.; Fahey, D.W.; Forster, P.M.; Newton, P.J.; Wit, R.C.N.; Lim, L.L.; Owena, B.; Sausen, R. Aviation and global climate change in the 21st century. Atmos. Environ. 2009, 43, 3520-3537. [CrossRef] [PubMed]

6. Aydin, H.; Turan, O.; Karakoc, T.H.; Midilli, A. Exergetic sustainability indicators as a tool in commercial aircraft: A case study for a turbofan engine. Int. J. Green Energy 2015, 12, 28-40. [CrossRef]

7. Schäfer, A.W.; Evans, A.D.; Reynolds, T.G.; Dray, L. Costs of mitigating $\mathrm{CO}_{2}$ emissions from passenger aircraft. Nat. Clim. Chang. 2016, 6, 412-417. [CrossRef]

8. Lee, J.J. Can we accelerate the improvement of energy efficiency in aircraft systems? Energy Convers. Manag. 2010, 51, 189-196. [CrossRef]

9. Altuntas, O. Designation of environmental impacts and damages of turbojet engine: A case study with GE-J85. Atmosphere 2014, 5, 307-323. [CrossRef]

10. Yuksel, B.; Balli, O.; Gunerhan, H.; Hepbasli, A.; Atalay, H. Exergetic and Environmental Analyses of Turbojet Engine. In Environmentally-Benign Energy Solutions; Springer: Cham, Switzerland, 2020.

11. Morsli, S.; Amina, S.; Ganaoui, M.E.; Ramenah, H. Computational simulation of entropy generation in a combustion chamber using a single burner. Entropy 2018, 20, 922. [CrossRef]

12. International Energy Agency. World Energy Outlook; IEA: Paris, France, 2018.

13. Cecere, D.; Giacomazzi, E.; Ingenito, A. A review on hydrogen industrial aerospace applications. Int. J. Hydrog. Energy 2014, 39, 10731-10747. [CrossRef]

14. Dincer, I.; Acar, C. A review on potential use of hydrogen in aviation applications. Int. J. Sustain. Aviat. 2016, 2, 74-100. [CrossRef]

15. Balli, O.; Sohret, Y.; Karakoc, T.H. The effects of hydrogen fuel usage on the exergetic performance of a turbojet engine. Int. J. Hydrog. Energy 2018, 43, 10848-10858. [CrossRef]

16. Stamatis, A.; Vinni, C.; Bakalis, D.; Tzorbatzoglou, F.; Tsiakaras, P. Exergy analysis of an intermediate temperature solid oxide fuel cell-gas turbine hybrid system fed with ethanol. Energies 2012, 5, 4268-4287. [CrossRef]

17. Elitzur, S.; Rosenband, V.; Gany, A. On-board hydrogen production for auxiliary power in passenger aircraft. Int. J. Hydrog. Energy 2017, 42, 14003-14009. [CrossRef]

18. Koroneos, C.J.; Dompros, A.; Roumbas, G.; Moussiopoulos, N. Advantages of the use of hydrogen fuel as compared to kerosene. Resour. Conserv. Recycl. 2005, 44, 99-113. [CrossRef]

19. Nalbant, Y.; Colpan, C.O.; Devrim, Y. Energy and exergy performance assessments of a high temperature-proton exchange membrane fuel cell based integrated cogeneration system. Int. J. Hydrog. Energy 2020, 45, 3584-3594. [CrossRef]

20. Mahmoudi, S.M.S.; Sarabchi, N.; Yari, M.; Rosen, M.A. Exergy and exergoeconomic analyses of a combined power producing system including a proton exchange membrane fuel cell and an organic rankine cycle. Sustainability 2019, 11, 3264. [CrossRef] 
21. Harsha, S. Liquid hydrogen as aviation fuel and its relative performance with commercial aircraft fuel. Int. J. Mech. Eng. Robot. Res. 2014, 1, 73-77.

22. Alayi, R.; Nemati, R.; Shamel, A.; Kasaeian, A.; Sarkaleh, M.K.; Ahmadi, M.H. Energetic and exergetic analysis hybrid solid oxide fuel cell systems and gas turbine (SOFC-GT). Math. Model. Eng. Prob. 2019, 6, 263-270. [CrossRef]

23. Khandelwal, B.; Karakurt, A.; Sekaran, P.R.; Sethi, V.; Singh, R. Hydrogen powered aircraft: The future of air transport. Prog. Aerosp. Sci. 2013, 60, 45-59. [CrossRef]

24. Nanaki, E.A.; Koroneos, C.J. Exergetic aspects of hydrogen energy systems-The case study of a fuel cell bus. Sustainability 2017, 9, 276. [CrossRef]

25. Bicer, Y.; Dincer, I. Life cycle evaluation of hydrogen and other potential fuels for aircrafts. Int. J. Hydrog. Energy 2017, 42, 10722-10738. [CrossRef]

26. Gohardani, A.S.; Doulgeris, G.; Singh, R. Challenges of future aircraft propulsion: A review of distributed propulsion technology and its potential application for the all electric commercial aircraft. Prog. Aerosp. Sci. 2011, 47, 369-391. [CrossRef]

27. Westenberger, A. Hydrogen fuelled aircraft. AIAA International Air and Space Symposium and Exposition. In Proceedings of the Next 100 Years, AIAA 2003-2880, Dayton, OH, USA, 14-17 July 2003.

28. Baroutaji, A.; Wilberforce, T.; Ramadan, M.; Olabi, A.G. Comprehensive investigation on hydrogen and fuel cell technology in the aviation and aerospace sectors. Renew. Sustain. Energy Rev. 2019, 106, 31-40. [CrossRef]

29. Sarlioglu, B.; Morris, C.T. More electric aircraft: Review, challenges and opportunities for commercial transport aircraft. IEEE Trans. Transp. Electrif. 2015, 1, 54-64. [CrossRef]

30. Blakey, S.; Rye, L.; Wilson, C.W. Aviation gas turbine alternative fuels: A review. Proc. Combust. Inst. 2011, 33, 2863-2885. [CrossRef]

31. International Coordinating Council of Aerospace Industries Associations. Non-drop in fuels and advanced aircraft system power technologies. In Proceedings of the Conference on Aviation and Alternative Fuels, CAAF/09-IP/13, Rio de Janeiro, Brazil, 16-18 November 2009.

32. Rivard, E.; Trudeau, M.; Zaghib, K. Hydrogen storage for mobility: A Review. Materials 2019, $12,1973$. [CrossRef] [PubMed]

33. ASTM. ASTMD1655-18a, Standard Specification for Aviation Turbine Fuels; ASTM International: West Conshohocken, PA, USA, 2018.

34. Naemi, S.; Avval, M.S.; Kalhori, S.B.; Mansoori, Z. Optimum design of dual pressure heat recovery steam generator using non-dimensional parameters based on thermodynamic and thermoeconomic approaches. Appl. Therm. Eng. 2013, 52, 371-384. [CrossRef]

35. Lazzaretto, A.; Tsatsaronis, G. SPECO: A systematic and general methodology for calculating efficiencies and costs in thermal systems. Energy 2006, 31, 1257-1289. [CrossRef]

36. Toffolo, A.; Lazzaretto, A. Evolutionary algorithms for multi-objective energetic and economic optimization in thermal system design. Energy 2002, 27, 549-567. [CrossRef]

37. Balli, O. Thermodynamic, thermoeconomic and environmental performance analyses of a commercial aircraft's high bypass turbofan engine. Sakarya Univ. J. Sci. 2019, 23, 453-461.

38. Cooper, J.; Dingle, L. Engineering an afterburner for a miniature gas turbine engine. Aircr. Eng. Aerosp. Technol. 2005, 77, 104-108. [CrossRef]

39. Li, H.; Chen, Y.; Tan, T.; Du, J.; Zhou, J.; Liu, C. Design and characteristic calculation of combustion chamber of hydrogen-fueled scramjet based on constant static temperature heating method. In Proceedings of the 2019 IEEE 10th International Conference on Mechanical and Aerospace Engineering (ICMAE), Brussels, Belgium, 22-25 July 2019.

40. Large, J.; Pesyridis, A. Investigation of micro gas turbine systems for high speed long loiter tactical unmanned air systems. Aerospace 2019, 6, 55. [CrossRef]

41. Sohret, Y.; Sogut, M.Z.; Karakoc, T.H.; Turan, O. Customised application of exergy analysis method to PW120A turboprop engine for performance evaluation. Int. J. Exergy 2016, 20, 48-65. [CrossRef]

42. Ekici, S.; Sohret, Y.; Coban, K.; Altuntas, O.; Karakoc, T.H. Performance evaluation of an experimental turbojet engine. Int. J. Turbo Jet Eng. 2017, 34, 365-375. [CrossRef]

43. Turan, O. An exergy way to quantify sustainability metrics for a high bypass turbofan engine. Energy 2015, 86, 722-736. [CrossRef] 
44. Kaya, N.; Turan, O.; Midilli, A.; Karakoc, T.H. Exergetic sustainability improvement potentials of a hydrogen fueled turbofan engine UAV by heating its fuel with exhaust gasses. Int. J. Hydrog. Energy 2016, 41, 8307-8322. [CrossRef]

45. Jin, Y.; Du, J.; Li, Z.; Zhang, H. Second-law analysis of irreversible losses in gas turbines. Entropy 2017, 19, 470. [CrossRef]

46. Ekici, S.; Altuntas, O.; Acikkalp, E.; Sogut, M.Z.; Karakoc, T.H. Assessment of thermodynamic performance and exergetic sustainability of turboprop engine using mixture of kerosene and methanol. Int. J. Exergy 2016, 19, 295-314. [CrossRef]

47. Coban, K.; Colpan, C.O.; Karakoc, T.H. Application of thermodynamic laws on a military helicopter engine. Energy 2017, 140, 1427-1436. [CrossRef]

48. Altayib, K. Energy, Exergy and Exergoeconomic Analyses of Gas Turbine Based Systems. Master's Thesis, University of Ontario Institute of Technology, Oshawa, ON, Canada, 2011.

49. Balli, O. Exergetic, exergoeconomic, sustainability and environmental damage cost analyses of J85 turbojet engine with afterburner. Int. J. Turbo Jet Eng. 2017, 34. [CrossRef]

50. Tsatsaronis, G. Recent developments in exergy analysis and exergoeconomics. Int. J. Exergy 2008, 5, 489-499. [CrossRef]

51. Aydin, H.; Turan, O.; Midilli, A.; Karakoc, T.H. Exergetic and exergoeconomic analysis of a turboprop engine: A case study for CT7-9C. Int. J. Exergy 2012, 11, 69-82. [CrossRef]

52. Balli, O. A parametric study of hydrogen fuel effects on exergetic, exergoeconomic and exergoenvironmental cost performances of an aircraft turbojet engine. Int. J. Turbo Jet Eng. 2019, 36. [CrossRef]

53. Altuntas, O.; Karakoc, T.H.; Hepbasli, A. Exergetic, exergoeconomic and sustainability assessment of piston-prop aircraft engine. Int. J. Therm. Sci. Technol. 2012, 32, 133-143.

54. Petrakopoulou, F.; Tsatsaronis, G.; Morosuk, T. Evaluation of a power plant with chemical looping combustion using an advanced exergoeconomic analysis. Sustain. Energy Technol. Assess. 2013, 3, 9-16. [CrossRef]

55. Petrakopoulou, F.; Tsatsaronis, G.; Morosuk, T.; Carassai, A. Advanced exergoeconomic analysis applied to a complex energy conversion system. ASME J. Eng. Gas Turbines Power 2012, 134, 1801-1808. [CrossRef]

56. Acikkalp, E.; Aras, H.; Hepbasli, A. Advanced exergoeconomic analysis of an electricity-generating facility that operates with natural gas. Energy Convers. Manag. 2014, 78, 452-460. [CrossRef]

57. Wei, Z.; Zhang, B.; Wu, S.; Chen, Q.; Tsatsaronis, G. Energy-use analysis and evaluation of distillation systems through avoidable exergy destruction and investment costs. Energy 2012, 42, 424-433. [CrossRef]

58. Tsatsaronis, G.; Morosuk, T. Advanced exergoeconomic evaluation and its application to compression refrigeration machines. In Proceedings of the ASME International Mechanical Engineering Congress and Exposition, Seattle, WA, USA, 11-15 November 2007.

59. Ochoa, G.V.; Rojas, J.P.; Forero, J.D. Advanced exergo-economic analysis of a waste heat recovery system using ORC for a bottoming natural gas engine. Energies 2020, 13, 267. [CrossRef]

60. Anvari, S.; Saray, R.K.; Bahlouli, K. Conventional and advanced exergetic and exergoeconomic analyses applied to a tri-generation cycle for heat, cold and power production. Energy 2015, 91, 925-939. [CrossRef]

61. Tsatsaronis, G.; Park, M.H. On avoidable and unavoidable exergy destructions and investment costs in thermal systems. Energy Convers. Manag. 2002, 43, 1259-1270. [CrossRef]

62. Cziesla, F.; Tsatsaronis, G.; Gao, Z. Avoidable thermodynamic inefficiencies and costs in an externally fired combined cycle power plant. Energy 2006, 31, 1472-1489. [CrossRef]

63. Yuksel, B.; Balli, O.; Gunerhan, H.; Hepbasli, A. Comparative performance metric assessment of a military turbojet engine utilizing hydrogen and kerosene fuels through advanced exergy analysis method. Energies 2020, 13, 1205. [CrossRef]

64. TurAF-Turkish Air Forces. 1'st Air Supply and Maintenance Center, Annually Operation and Maintenance Report; First Air Supply and Maintenance Center: Eskisehir, Turkey, 2019.

65. National Research Council (US). Permissible Exposure Levels for Selected Military Fuel Vapors; The National Academies Press: Washington, DC, USA, 1996.

66. Abe, I. Physical and chemical properties of hydrogen. Energy Carriers Convers. Syst. 2012, 1, 1-3.

67. Vatani, A.; Mehrpooya, M.; Palizdar, A. Advanced exergetic analysis of five natural gas liquefaction processes. Energy Convers. Manag. 2014, 78, 720-737. [CrossRef]

68. Sohret, Y.; Acikkalp, E.; Hepbasli, A.; Karakoc, T.H. Advanced exergy analysis of an aircraft gas turbine engine: Splitting exergy destructions into parts. Energy 2015, 90, 1219-1228. [CrossRef] 
69. Kelly, S.; Tsatsaronis, G.; Morosuk, T. Advanced exergetic analysis: Approaches for splitting the exergy destruction into endogenous and exogenous parts. Energy 2009, 34, 384-391. [CrossRef]

70. Balli, O. Advanced exergy analyses of an aircraft turboprop engine (TPE). Energy 2017, 124, $599-612$. [CrossRef]

71. Callak, M.; Balkan, F.; Hepbasli, A. Avoidable and unavoidable exergy destructions of a fluidized bed coal combustor and a heat recovery steam generator. Energy Convers. Manag. 2015, 98, 54-58. [CrossRef]

72. Shivam, M.; Sohret, Y.; Sanjay, O. Advanced exergy analysis of aero gas turbine cycle based on air-film blade cooling. In Proceedings of the International Symposium on Sustainable Aviation, ISSA-2017-302, Kiev, Ukraine, 10-13 September 2017.

73. Petrakopoulou, F.; Tsatsaronis, G.; Morosuk, T.; Carassai, A. Conventional and advanced exergetic analyses applied to a combined cycle power plant. Energy 2012, 41, 146-152. [CrossRef]

(C) 2020 by the authors. Licensee MDPI, Basel, Switzerland. This article is an open access article distributed under the terms and conditions of the Creative Commons Attribution (CC BY) license (http://creativecommons.org/licenses/by/4.0/). 